NBSIR 84-2867

\title{
Test Procedures for Rating Residential Heating and Cooling Absorption Equipment
}

U.S. DEPARTMENT OF COMMERCE

National Bureau of Standards

Center for Building Technology

Building Equipment Division

Washington, DC 20234

April 1984

Sponsored by:

Oak Ridge National Laboratory

QC

U.S. Department of Energy

100 Oak Ridge, Tennessee 37830 



\section{TEST PROCEDURES FOR RATING}

RESIDENTIAL HEATING AND COOLING

ABSORPTION EQUIPMENT

Brian Weber

Reinhard Radermacher

David Didion

U.S. DEPARTMENT OF COMMERCE

National Bureau of Standards

Center for Building Technology

Building Equipment Division

Washington, DC 20234

April 1984

\section{Sponsored by:}

Oak Ridge National Laboratory

U.S. Department of Energy

Oak Ridge, Tennessee 37830

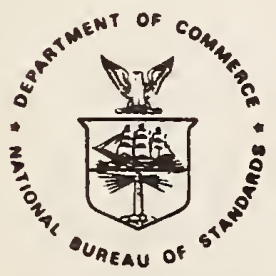

U.S. DEPARTMENT OF COMMERCE, Malcolm Baldrige, Secretary 



\section{AB STRACT}

Test and rating procedures are presented for gas-fired absorption devices operating in either the heating or cooling modes. These procedures are designed to include the effects of part-load and cyclic operation, variations in outdoor temperature, and frost formation during the heating mode. Both airsource and ground water source absorption heat pums are considered, as well as air cooled and ground water cooled air conditioners and water chillers. A calculation procedure is presented for estimating the heating and cooling seasonal performance and cost of operation of residential water chillers, air conditioners, and heat pump units.

Key rords: Central air conditioners; central heating equipment; heat pump; heating seasonal performance; cooling seasonal performance; rating procedure; seasonal cost of operation; test method. 


\section{ACKN ONLEDG EMENTS}

This study was sponsored by the U.S. Department of Energy, Office of Building Energy Research and Development through the program management service of Mr. Robert DeVault of the Energy Division of Oak Ridge National Laboratory.

The support of R. Radermacher during this investigation by acholarship from the NATO Science Committee by the German Academic Exchange Service is grateful1y acknowledged. 
SI CONVERSION FACTORS ........................ ... .1

1. INTRODUCTION . . . . . . . . . . . . . . . . . . . 1

1.1 Backgronnd . . . . . . . . . . . . . . . . . . 1

1.2 Comparison of Different Residential Size Systems . . . . . 2

1.3 Classification of Absorption Systems . . . . . . . . . 2

1.4 Objective and Scope.................... . . . . . 4

2. RECOMMENDED RATING REQU IREMENTS . . . . . . . . . . . . . . 6

2.1 General . . . . . . . . . . . . . . . . . 6

2.1 .1 Cooling Systems ................... 6

2.1 .2 Heating Systems ................... . . . . 6

2.2 Cooling Systems . . . . . . . . . . . . . . . . . 8

2.2.1 Standard Rating Test . . . . . . . . . . . . 8

2.2.2 Steady-State Tests ................. . . . 8

2.2 .3 Cyclic Test ...................... 10

2.2 .4 Summaty ....................... . . . . . 11

2.3 Heating Systems...................... . . . . . . . 12

2.3.1 Standard Rating Test................ 12

2.3 .2 Steady-State Tests.................. 12

2.3.3 Frost-Accumnlation Test ............... 12

2.3 .4 Cyclic Test ...................... 13

2.3 .5 Summary ...................... . . . . . . . . 14

2.4 Suggested Rating Sheets . . . . . . . . . . . . . . 14

3. RECOMMENDED TEST PROCEDURE FOR ABSORPTION COOLING SYSTEMS . . . . 16

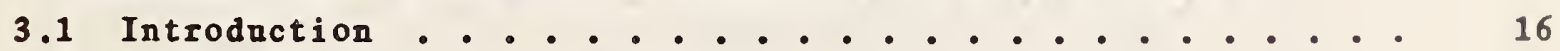

3.2 Sterdy-State Test Procedure.................. . . . 16

3.2.1 Applicable Test Method ................ 16

3.2.2 Instrumentation and Required Data . . . . . . . . . 17

3.2.3 Test Operating Procedure and Results . . . . . . . 17

3.2 .4 Test Tolerances ................. . . . 18

3.3 Cyclic Test Procedare . . . . . . . . . . . . . . . 19

3.3.1 Applicable Test Method................ 19

3.3.2 Instrumentation and Required Data . . . . . . . . 19

3.3.3 Test Operating Procedure and Results ......... 19

3.3.4 Test Tolerances ................. 20

4. MODEL LOADS AND CLIMATE SPECIFICATIONS FOR ABSORPTION

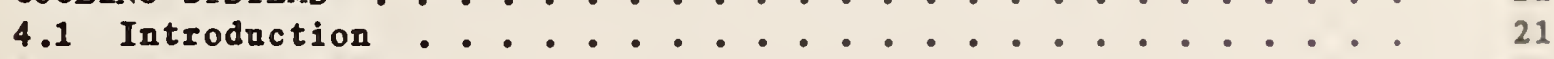

4.2 Building Loads . . . . . . . . . . . . . . . . 22 
5. CALCULATION PROCEDURE FOR ABSORPTION COOLING SYSTEMS . . . . . . 24

5.1 Introduction . . . . . . . . . . . . . . . . . . . 24

5.2 Calculation Procedure for Steady-State Tests . . . . . . . 24

5.2.1 Fuel Energy Input ................ 24

5.2 .2 Electrical Energy Input ............. 24

5.2.3 Cooling Capacity................. 25

5.2.4 Heat Balance - Confirming Test . . . . . . . . . 26

5.3 Calculation Procedure for Cyclic Test . . . . . . . . . 27

5.4 Coefficient of Performance . . . . . . . . . . . . . 29

5.5 Seasonal Performance Factor and Seasonal Operating Costs . . 29

5.6 Sample Calculation .................. 32

6. RECOMMENDED TEST PROCEDURE FOR ABSORPTION HEATING SYSTEMS . . . . 35

6.1 Introduction . . . . . . . . . . . . . . . . . . 35

6.2 Steady-State Test Procedure . . . . . . . . . . . . 35

6.2.1 Applicable Test Method ............... 35

6.2.2 Instrumentation and Required Data . . . . . . . 36

6.2.3 Test Operating Procedure and Results........ 36

6.2 .4 Test Tolerances ................ . . . 37

6.3 Cyc1 ic Test Procedure . . . . . . . . . . . . . . . 38

6.3.1 Applicable Test Method ................ 38

6.3.2 Instrumentation and Required Data . . . . . . . . 38

6.3.3 Test Operating Procedure and Results . . . . . . . 38

6.3.4 Test Tolerances ................. 39

6.4 Frost Accumulation Test Procedure . . . . . . . . . . 39

6.4.1 Appl icable Test Method .............. . 39

6.4.2 Instrumentation and Required Data ........ 39

6.4.3 Test Operating Procedure and Results........ . 39

6.4.4 Test Tolerances ................ 40

7. MODEL LOADS AND CLIMATE SPECIFICATIONS FOR ABSORPTION

HEATING SYSTEMS . . . . . . . . . . . . . . . 41

7.1 Introduction ....................... . . . . . 41

7.2 Building Loads ...................... . . . . 42

8. CALCULATION PROCEDURE FOR ABSORPTION HEATING SYSTEMS . . . . . . 43

8.1 Introduction . . . . . . . . . . . . . . . . 43

8.2 Calculation Procedure for Steady-State Tests . . . . . . 43

8.2.1 Fuel Energy Input ................. 43

8.2.2 Electrical Energy Input ............. 43

8.2.3 Cooling Capacity ................. . . . 44

8.2.4 Heat Balance - Confirming Test............ 44

8.3 Calculation Procedure for Cyclic Test . . . . . . . . . 46

8.4 Coefficient of Performance . . . . . . . . . . . . . 47

8.5 Seasonal Performance Factor and Seasonal Operating Costs . . 48

8.6 Sample Calculation .................. 50

9. LIMITATIONS OF THE RECOMAIENDED TEST AND RATING PROCEDURE . . . . 54

REFERENCES . . . . . . . . . . . . . . . . . . . 55 


\section{LIST OF TABLES}

$\underline{\text { Page }}$

TABLE 1

TABLE 2

TABLE 3

TABLE 4

TABLE 5

TABLE 6

TABLE 7

TABLE 8

TABLE 9

TABLE 10

TABLE 11
SUMMARY OF TESTING REQUIREMENTS FOR DIRECT-FIRED AIR-COOLED AND WATER-COOLED ABSORPTION COOLING SYSTEMS .................. 56

SUMMARY OF TESTING REQUIREMENTS FOR DIRECT-FIRED AIR-SOURCE AND WATER-SOURCE ABSORPTION HEATING SYSTEMS . . . . . . . . . . . . . . . . 57

RATING SHEET FOR DIRECT-FIRED ABSORPTION COOLING SYSTEMS ... . . . . . . . . . . . . . 58

FRACTIONAL TEMPERATURE BIN HOURS FOR COOLING SEASONAL CALCULATION . . . . . . . . . . . . 59 DISTR IBUTION OF ACTUAL COOLING LOAD HOURS (CLH) THROUGHOUT THE UNITED STATES . . . . . . . . . 60

RATING SHEET FOR DIRECT-FIRED ABSORPTION HEATING SYSTEMS ...................... 61 MAJOR CLIMATIC REGIONS IN THE CONTINENTAL USA . . . . 62 HEATING LOAD HOURS (HLH) FOR THE UNITED STATES . . . 63 RECOMMENDED CALCULATION SHEET FOR DETERMINING SPF AND SOC OF DIRECT-FIRED ABSORPTION SYSTEMS . . . . . . 64 SAMPLE CALCULATIONS FOR ABSORPTION COOLING SYSTEMS . 65 SAMPLE CALCULATIONS FOR ABSORPTION HEATING SYSTEMS • . 66 


\title{
NOMENCL ATORE
}

\author{
$B L\left(T_{j}\right)$ Building load at an outdoor dry-bulb temperature $T_{j}$, $k W$ (lBta/hr). \\ Cooling. \\ $\mathbf{C}_{\mathbf{D}}$ \\ Degradation factor for cyclic operation, defined by equation (5.13). \\ $\mathrm{C}_{\mathrm{e}}$ \\ Cost of electricity in $\$ /$ Thr. \\ $\mathbf{C}_{\mathbf{f}}$ \\ Cost of fuel in $\$ / B t a$. \\ CLF \\ Cooling load factor, defined as the ratio of the total cyclic \\ cooling done in a complete cycle or specified period consisting of \\ an 'on'time and an 'off'-time to the steady-state cooling done over \\ the same time period at constant ambient conditions. See equation \\ (5.11).
}

CLH Cooling load hours, defined as the number of hours in a cooling season that a building requires cooling. See Table 4.

COP Coefficient of performance, defined as the net heating done over a specified period of time divided by the total electrical energy and fuel energy input over the same time interval.

Specific heat (heat capacity) $\mathrm{kJ} / \mathrm{kg}^{\circ} \mathrm{C}$ (Bta/1bm $\left.{ }^{\circ} \mathrm{F}\right)$.

Specific heat at constant pressure of air-water mixture per pound of dry air.

CSPF Cooling seasonal performance factor, defined as the ratio of the total cooling done to the total energy usage over a cooling season.

DHR Design Heating Requirement (steady-state heating capacity at outdoor design temperature, $\left.T_{h}\right), k W(k B t a / h r)$.

E

Total energy consumption during entire season kWhr, (kBta).

$E_{s s}(T)$ Steady-state total energy input at a given water temperature $T, k W$ (kBta/hr).

$E\left(T_{j}\right) \quad$ Total energy consumption at an outdoor dry-bulb temperature, $T_{j} \cdot k W$ $(\mathrm{kBta} / \mathrm{hr})$.

h Heating.

HHV Higher heating value of fuel on a mass basis. 
RIF

Heating load factor, defined as the ratio of the total cyclic heating done in a complete cycle of specified period consisting of an 'on'-time and 'off'-time to the steady-state heating done orer the time period at constant ambient conditions. See equation $(8.10)$.

BLH

Heating load hours. See Table 7 .

HSPF Heating seasonal performance factor, defined as the ratio of the total heating done to the total energy usage over a heating season.

Oatdoor dry-bulb temperature bin number. See Tables 4 and 7 .

$\dot{\mathbf{m}}_{\mathrm{f}}$

N

$\mathbf{n}_{\mathbf{j}}$

n

$\underline{n_{i}}$

N

PLF

$\mathbf{P}_{\mathbf{t}}$

$Q_{\text {cyc }}$

$Q_{f}$

$\mathbf{Q}_{\mathbf{j}}$

Qsc

Fue1 mass flow rate. See equation (5.1).

Total number of temperature bin hours.

Number of temperature bin hours in a particular bin.

Number of non-zero temperature bins.

Fractional number of temperature bin hours. See Tables 4 and 7.

Part-load factor, defined as the ratio of the cyclic COP to the steady-state COP, see equation (5.14).

Total amount of electrical energy being supplied averaged over the test duration, $k W(k B t u / h r)$.

Cyclic total capacity defined as the ratio of the total cooling done over a given time period to the duration of time the burner is on in that period, kW (kBtr/hr).

Residual energy in the products of combustion (flue gas) leaving the system, $K$ T $(\mathrm{kBtu} / \mathrm{hr})$.

Jacket heat loss representing the convective and radiative losses from heated metal surfaces, $k$ W (kBtu/hr).

Air flow rate across the condenser and absorber coils, $k g / h r(1 b m / h r$ or (FF). 
QS (T) Total steady-state cooling or heating capacity at a water temperature T, $k W(k B t a / h r)$.

$Q_{8}$

$\dot{Q}_{\text {SS }}$

RH $R H\left(T_{j}\right)$ Resistance heat energy usage in temperature bin, $T_{j}, k W h r$, see
equation $(8.15)$.

SOC

SPF

$\mathrm{T}_{\mathrm{c}}$

$\mathrm{T}_{\mathbf{h}}$

$\mathbf{T}_{\mathbf{j}}$

t

站

$\mathbf{v}_{\mathbf{n}}$

$\mathbf{W}_{\mathbf{n}}$

Rate of thermal energy supplied to the generator, kW (kBta/hr).

Steady-state capacity, $k \mathbb{W}(\mathrm{kBta} / \mathrm{hr})$.

Auriliary electric resistance heating, kW.

Seasonal Operating Costs of direct-fired absorption systems.

Seasonal performance factor, defined as the ratio of the total cooling or heating done to the total energy over a cooling or heating season.

specified outdoor change-over temperature.

Outdoor design temperature (also $\mathrm{T}_{\mathrm{OD}}$ ).

Representative outdoor dry-bulb temperature for temperature bin $j$, ${ }^{\circ} \mathrm{C}\left({ }^{\circ} \mathrm{F}\right)$. See Tables 4 and 7 .

Time, hours.

Indoor air flow rate, $\mathrm{m}^{3} / \mathrm{s}$ (CFM), at the dry-bulb temperature, humidity ratio, and pressure existing in the region of measurement.

Specific volume of air water mixture, at the same dry-bulb

temperature, humidity ratio, and presşre used in the determination of the indoor air flowrate, $\mathrm{m}^{3} / \mathrm{kg}\left(\mathrm{ft}^{3} / 1 \mathrm{bm}\right)$.

Bumidity ratio, (the ' $n$ ' means at the nozzle [i.e., point of measurement for airflowrate]). $\mathrm{kg} / \mathrm{kg}(1 \mathrm{bm} / 1 \mathrm{bm})$. 


\section{SI CONVERSION FACTORS}

\section{MULTIPLY}

Bta/h, Btah

$\mathrm{Bta} / 1 \mathrm{bm}^{\circ} \mathrm{F},\left[\mathrm{C}_{\mathrm{p}}\right.$, specific heat $]$

- $F$

$f t$

$f t / m i n, f p m$

$f t^{3} / 1 b m$

$\mathrm{ft}^{3} / \mathrm{min}, \mathrm{CFM}$

$\mathrm{gpm}$ (US)

inch

inch of water

$\mathrm{kBta} / \mathrm{h}$

$1 \mathrm{bm} / \mathrm{h}$

ton of refrigeration capacity
$\underline{B Y}$

0.293

4.19

${ }^{\circ} \mathrm{C}=\left({ }^{\circ} \mathrm{F}-32\right) / 1.8$

0.3048

0.00508

0.0623

0.472

0.0631

25.4

3.38

1055

0.126

3516
TO OBTAIN

T

$\mathbf{k J} / \mathbf{k} \mathrm{g}^{\circ} \mathrm{C}$

m

m/s

$m^{3} / 18$

$m^{3} / s$

L/S

mm

$\mathbf{k P a}$

kJ

$8 / 5$

W 



\section{INTRODUCTION}

\subsection{Background}

Absorption cycle air-conditioning and refrigerating equipment have been in standard production for decades, and have been designed for residential, commercial, and industrial applications. Absorption cycle heat pmps are currently being developed for introduction into the marketplace. Absorption equiment has typically been driven by such energy sources as fossil fuels and waste and process steam. Capacities have ranged from three kW to approximately seven MW ( 3 to 2000 tons). Coefficients of performance based on full load steady-state operation testing, have varied from 0.4 to values near 1.0 , depending upon whether the machine is a single or double-effect design. The efficient performance of absorption equipment is dependent on many operating and design variables including the temperatures at which energy is supplied and rejected, the load imposed by the conditioned space, the required chilled fluid temperature, various solution and fluid flow rates, and the refrigerant and absorbent fluids selected.

Because of worldwide energy concerns and the increasing scarcity of some forms of energy, the efficient use of absorption equipment has recently come into sharper focus. As a result, new and more energy efficient designs are being developed by various groups and agencies in this country and abroad. Accordingly, there is an increasing need by industry, government, and the consumer to be able to evaluate and compare these improved systems on the same technical basis. A standardized test and rating procedure which incorporates provisions specifically tailored to the nature of each type of absorption system is required in order to effectively compare overall system performance. Such a test and rating procedure is the subject of this report. 


\subsection{Comparison of Different Residential Size Systems}

In order to compare different residential size systems such as absorption or vapor compression airconditioners or heat pump, the following caution should be taken into account. The performance of a cooling or heating system is not only dependent upon the unit itself but also of the characteristics of the thermostat which controls the cycling rate. Differences in thermostats can result in cycling time lengths of unequal duration leading to fluctuations in indoor temperatures, and consequently different energy performance of the cooling or heating device. In this test procednre the anit is operated according to the charcteristics of the thermostat provided by the manufacturer; however, the results of this procedure do not show differences in the comfort for inhabitants of a room due to humidity and temperature variations during a cycle, nor does it measure the effects on equipment life as a result of the total number of cycles required to meet the seasonal load.

\subsection{Classification of Absorption Systems}

Absorption systems are identified according to the following classification:

- Type of Service

- cooling

- heating

- both heating and cooling (reversible)

- Energy Source

- direct-fired (gas or oil combustion)

- hot water (steam)

- Application

- residential

- commercial 
- industrial

- Sink/Source Medium

- air

- water

A further characterization of a system includes whether the generator anit is single-effect or double-effect, and a specification of the refrigerant/absorbent fluid pair.

All commercially available absorption systems are currently designed for cooling service only. There are, however, several heat-only and reversible absorption systems currently under development. These systems are designed for direct firing with oil or gas, or the use of waste or process steam to provide high temperature hot water.

In this report the terminology and classification scheme used for cooling and heating systems is as shown below:
Air cooled $\equiv$ refers to units rejecting heat to air
Water cooled E refers to units rejecting heat to water
Air source $\equiv$ refers to units absorbing heat from air
Water source $\equiv$ refers to units absorbing heat from water

\section{Heating Systems}

\section{Outdoor Side}

Air Source - outdoor air temperature entering evaporator

Water Source - ground water temperature entering evaporator 
Indoor Side

Hot Air Heat - indoor return air temperature

Hot Water Heat - indoor return water temperature

\section{Cooling Systems}

Outdoor Side

Air Sink - (i.e., air cooled) outdoor air temperature entering condenser

Water Sink - (i.e., water cooled) ground water temperature or cooling tower water temperature entering condenser

Indoor Side

Air Conditioners - indoor return air temperature

Water Chillers - indoor return water temperature

\subsection{Objective and Scope}

The objective of this study is to develop generic test and rating procedures for absorption cooling and heating systems which are likely to be employed in residential and 1 ight commercial building both now and in the futare. Where feasible, the proposed procedures include the formulation of calculation procedures to estimate the seasonal performance and seasonal cost of operation of these systems. The intent of the proposed procedures is to provide a means whereby the performance of prototype and production type absorption systems having different design characteristics may be meaningfully compared on the same technical basis, and sound decisions may be made regarding which systems are worthy of further development or application. 
The test, rating, and calculation procedures recommended berein apply only to residential and light commercial cooling and beating applications of the 10.6$52.8 \mathrm{~kW}$ (3-15 tons) capacity range. The procedures are restricted to directfired systems, (since these are the most likely to emerge in the residential and small commercial markets). They ere sufficiently general, however, to include both air-cooled and water-cooled systems. The procedures are intended to be applicable to both single-effect and double-effect machines using any refrigerant/absorbent fluids, and essentially treat the absorption system as a 'black box' with energy inputs and outputs. Therefore, these procedures are as independent of thermodynamic and thermal design specifics as possible. 


\section{RECOMMENDED RATING REQU IREMENTS}

\subsection{Genera 1}

The recommended rating requirements for the absorption systems considered in this study are classified according to whether the systems are designed for cooling or heating applications. For cooling applications (i.e., waterchilling and air-conditioning), those systems which reject heat to water are further divided according to whether heat is rejected to ground water or to an air-cooled device (cooling tower). For heating applications, the systems are divided according to whether they deliver heat to air or water.

\subsubsection{Cooling Systems}

The rating requirements for these systems include a single steady-state maximum load rating test at specified condenser unit cooling fluid inlet temperature and chilled fluid conditions, one or two steady-state part load performance tests (to account for frost accumalation and high temperature operation) and a cyclic test. The rating test is a maximum load test, run at the 'design' conditions that are established close to the most severe operating conditions likely to be found in the field. The steady-state part load tests cause the unit to operate at the same maximum energy input but at a different refrigerant flow rate. The cyclic test will result in the unit operating to meet load either by cycling or modulation depending on the unit's control logic.

\subsubsection{Heating Systems}

The rating requirements for heating systems include a steady-state rating test (1ow-temperature test) at conditions specified in Table 2 . This test is at maximum load at conditions that are established close to the most severe 
ambient conditions to be found in the field. A frost accumation test is required only for air source systems and is to be run at an outdoor $\mathrm{DB} / \mathrm{WB}$ temperature of $1.7^{\circ} \mathrm{C}\left(35^{\circ} \mathrm{F}\right) /-1.1^{\circ} \mathrm{C}\left(30^{\circ} \mathrm{F}\right)$. A second steady-state test (hightemperature test) is to be run with both air and water source systems. In order to account for the performance degradation due to the unit cycling on and off, a cycling test is also specified. This test is to be run at the same conditions as the high temperatnre test for both airsource systems and water sorrce systems.

These tests on direct-fired systems provide data necessary to construct performance curves which provide a basis for calculating the system's seasonal performance factor and seasonal cost of operation.

A summsy of the recommended testing requirements for direct-fired systems is presented in Tables 1 and 2. Recommended rating sheets for the various systems are shown in Tables 3 and 6.

It should be noted that this document differs from the ARI Standard (Ref.9) for absorption water chillers in its specification of the evaporator water temperature. Whereas the ARI Standard specifies the water temperature leaving the evaporator, here the temperature of the water entering the evaporator is specified. This alteration was necessary to specify a definite chilled water temperature condition for the cyclic test, which is not covered in the ARI document. 


\subsection{Cooling Systems}

\subsubsection{Standard Rating Test}

A Standard Rating Test shall be conducted according to the test procedares specified in Section 3.2 , and the performance calculated according to the procedures discussed in Section 5. In order that the performance of different absorption systems may be compared, the results of the rating tests and the calculated performance shall be reported. Results to be reported are discussed in Section 2.4 and illustrated in Table 3.

\subsubsection{Steady-State Tests}

A total of three steady-state tests (A, B, C, see Table 1) shall be conducted for direct-fired absorption air-conditioners. Test $A$ is run at the standard rating conditions 1 isted in Table 1 . Test $B$ is conducted at different condenser fluid inlet conditions, selected to conform with other (nonabsorption type) air-conditioner standards (Ref, 3, 5, 7, 8). The condenser fluid inlet temperature values in these other standards were selected as typical field application values. Test $C$ is intended to provide data for the calculation of the seasonal performance factor and to determine the performance of airconditioners under dry evaporator coil conditions.

For direct-fired absorption water chillers, Tests $A$ and $C$ shall be conducted. Test B is not applicable.

For systems rejecting heat to air the dry-bulb temperature of the ambient air sha11 be $35^{\circ} \mathrm{C}\left(95^{\circ} \mathrm{F}\right)$ for Test $\mathrm{A}$, and sha11 be $27.8^{\circ} \mathrm{C}\left(82^{\circ} \mathrm{F}\right)$ for Tests $\mathrm{B}$ and $\mathrm{C}$. The first ambient condition coincides with the ARI Standard rating point for cooling equipment that rejects heat to the outside air. The $27.8^{\circ} \mathrm{C}\left(82^{\circ} \mathrm{F}\right)$ 
dry-bulb temperature for Test $C$ is chosen because it approximates the average operating temperature of many climates within the U.S. during the cooling season. The data of both steady-state tests are necessary to evaluate the seasonal performance of the system.

For systems which reject heat to a separate aircooled condenser (cooling tower), the condenser unit inlet water temperatures shal be $35^{\circ} \mathrm{C}\left(95^{\circ} \mathrm{F}\right)$ for Test $A$ and $23.9^{\circ} \mathrm{C}\left(75^{\circ} \mathrm{F}\right)$ for Tests B and C. For systems which reject heat to ground water, the condenser inlet temperatures shall be $21.1^{\circ} \mathrm{C}\left(70^{\circ} \mathrm{F}\right.$ ) for Test A and $15.6^{\circ} \mathrm{C}\left(60^{\circ} \mathrm{F}\right)$ for Tests $\mathrm{B}$ and $\mathrm{C}$ respectively. The $21.1^{\circ} \mathrm{C}\left(70^{\circ} \mathrm{F}\right)$ condition does not coincide with the ANSI Standard rating point of $23.9^{\circ} \mathrm{C}\left(75^{\circ} \mathrm{F}\right)$ (Ref. 2) for water cooled equipment; however, it does agree with reference (5) which in turn concurs with the ARI Standard (Ref. 7). The $15.6^{\circ} \mathrm{C}\left(60^{\circ} \mathrm{F}\right)$ condition selected is representative of ground water temperatures that are likely to occur in the field mach of the time.

For air-conditioning equipment, the dry-bulb and wet-bulb temperatures of the air entering the cooling coil shall be $26.7^{\circ} \mathrm{C}\left(80^{\circ} \mathrm{F}\right)$ and $19.4^{\circ} \mathrm{C}\left(67^{\circ} \mathrm{F}\right)$, for Tests A and B. For Test C the dry-bulb and wet-balb temperatures of the entering air shal 1 be $26.7^{\circ} \mathrm{C}\left(80^{\circ} \mathrm{F}\right)$ and a 1 ow enough wet-bulb temperature to insure that the indoor cooling coil is not condensing moistare (dry coil). For water-chillers, the temperature of chilled water ontering tho ovaporator coil shall be $12.8^{\circ} \mathrm{C}\left(55^{\circ} \mathrm{F}\right)$ for al 1 threetests (A, C, D). The returnair dry-bulb/wet-bulb condition of $26.7^{\circ} \mathrm{C} / 19.4^{\circ} \mathrm{C}\left(80^{\circ} \mathrm{F} / 67^{\circ} \mathrm{F}\right)$ for a was chosen to coincide ith the ANSI standard rating points for airconditioners. 


\subsubsection{Cyclic Test}

To complete the series of tests one cyclic test, $D$, is recommended for an evaluation of the performance degradation due to off-cycle refrigerant migration and heat loss. The cyclic performance test shall be performed immediately following Test $C$. The steady-state Test $C$ results and the cyclic test results are used together to find the performance degradation.

There are two possible designs for adjusting the capacity of direct-fired absorption air-conditioners and water-chillers to the building load. The first is modulating the fuel flow rate to the burner and the second by operating the system only for 1 imited periods of time at full capacity so that the time-averaged capacity meets the building load. The 1 ast method is the type found in current production models of the capacity range of concern, and is therefore the only one addressed here.

In order to calculate cycling losses and incorporate its effect in an air conditioner's seasonal performance and seasonal operating costs, it is necessary to couple the results of the cyclic test with the steady-state tests which is done by means of the part load factor:

$$
\text { PLF }=\frac{\text { COP }}{\text { cyc }}
$$

In the case of air-conditioners the following assumption is made in order to consider the fact that a dry or wet cooling coil might occur:

$$
\mathrm{PLF}=\left.\frac{\mathrm{COP}_{\mathrm{cyc}}}{\mathrm{COP}_{\mathrm{ss}}}\right|_{\mathrm{dry}}=\left.\frac{\mathrm{COP}_{\mathrm{cyc}}}{\mathrm{COP}_{\mathrm{ss}}}\right|_{\text {wet }}
$$


For air-conditioners and chillers the dry-bulb and wet-bulb temperatures for Test D are the same as those of Test C. Similarly, the condenser ambient condition is identical to Test C: for nnits rejecting heat to air the ontdoor dry-bulb temperature sha11 be $27.8^{\circ} \mathrm{C}\left(82^{\circ} \mathrm{F}\right)$; for units rejecting heat to ground water the entering water temperature shall be $15.6^{\circ} \mathrm{C}\left(60^{\circ} \mathrm{F}\right)$ and for units rejecting heat to cooling tower water the entering water temperature $\operatorname{shal1}$ be $23.9^{\circ} \mathrm{C}\left(75^{\circ} \mathrm{F}\right)$.

Daring the cyclic test the systems shall be operated by the control-devices supplied by the manufacturer. Tests shall be conducted with the burner on $20 \%$ of the cycle time and of $80 \%$ of the time. Current absorption air conditioners incorporate a thermostat set at a marimum cycling rate of $11 / 2$ cycles per hour at a $50 \%$ on-time. Assuming a pabolic thermostatic control curve, the resulting burner on and off-times are 12 minntes and 48 minutes respectively. However, if comparison with vapor compression systems is intended, the on- of time should be identical to the latter system. References (3) and (4) recommend a $20 \%$ part $10 \mathrm{ad}$ test to be achieved with six minutes on-time and 24 minntes off-time for these system comparisons.

\section{2 .4 Summary}

The test requirements for direct-fired air-conditioning and water-chilling systems are summarized in Table 1. The results of these tests shall be used to calculate system cooling capacity and coefficient of performance of each system tested, and shall also be used to calculate the seasonal performance factor and seasonal operating cost. Pertinent test data and calculated results shall be reported according to the recomended rating sheets discussed in Section 2.4 and illustrated in Table 3. 


\subsection{Heating Systems}

\subsubsection{Standard Rating Test}

The Standard Rating Test shall be conducted according to the test procedures specified in Section 6.2 and the performance calculated according to the procedure discussed in Section 8. In order that the performance of different absorption systems may be effectively compared, the results of the rating tests and the calculated performance shall be reported. Results to be reported are discussed in Section 2.4 and illustrated in Table 4.

\subsubsection{Steady-State Tests}

Two steady-state tests (A and C, see Table 2), shall be conducted for directfired absorption heat pumps.

For air source systems the dry-bulb and wet-bulb temperatures of the ambient a if shal1 be $8.3^{\circ} \mathrm{C}\left(47^{\circ} \mathrm{F}\right)$ and $6.1^{\circ} \mathrm{C}\left(43^{\circ} \mathrm{F}\right)$, respectively, for Test $\mathrm{A}$, and sha11 be $-8.3^{\circ} \mathrm{C}\left(17^{\circ} \mathrm{F}\right)$ and $-9.4^{\circ} \mathrm{C}\left(15^{\circ} \mathrm{F}\right)$ for Test C. For water source systems the evaporator inlet water temperature sha11 be $21.1^{\circ} \mathrm{C}\left(70^{\circ} \mathrm{F}\right)$ during Test $\mathrm{A}$ and $15.6^{\circ} \mathrm{C}\left(60^{\circ} \mathrm{F}\right)$ for Test C. The $15.6^{\circ} \mathrm{C}\left(60^{\circ} \mathrm{F}\right)$ condition is representative of ground water temperatures that frequently occur in the field.

\subsubsection{Frost-Accumulation Test}

The frost accumalation Test B applies only to air source systems. Air temperatures entering the evaporator and surrounding the outdoor portion of the unit shall have ambient $d r y-b u l b$ and dew-point temperatures of $1.7^{\circ} \mathrm{C}$ $\left(35^{\circ} \mathrm{F}\right)$ and $-1.1^{\circ} \mathrm{C}\left(30^{\circ} \mathrm{F}\right)$, respectively. Air entering the indoor heating coil of an air heating system shall have a dry-bulb temperature of $21.1^{\circ} \mathrm{C}\left(70^{\circ} \mathrm{F}\right)$ 
and maximum indoor wet-bulb temperature of $15.6^{\circ} \mathrm{C}\left(60^{\circ} \mathrm{F}\right)$. For a hot water heating system the entering water temperature shall be $40.6^{\circ} \mathrm{C}\left(105^{\circ} \mathrm{F}\right)$.

\subsubsection{Cyclic Test}

The final test required is a cyclic Test $D$, which evaluates the performance degradation due to off-cycle refrigerant migration and heat losses.

The cyclic performance test shall be performed immediately following the high temperature Test A. The dry-bulb temperatare and the wet-bulb temperature of the air entering the outdoor portion of an airsource unit shall be the same as in the high temperature test. Similarly, the dry and wet-bulb temperatures of the air entering and surrounding the indoor portion of air-source units shal1 be the same as Test $A\left(21.1^{\circ} \mathrm{C}\left(70^{\circ} \mathrm{F}\right)\right)$ dry-bolb, $\left(15.6^{\circ} \mathrm{C}\left(60^{\circ} \mathrm{F}\right)\right)$ maximum wet-bulb. The entering water temperature for hot water systems shall again be $40.6^{\circ} \mathrm{C}\left(105^{\circ} \mathrm{F}\right)$. For watersource, systems the cyclic performance test shall also be run immediately following the high temperature (steady-state) test. The entering water temperature and flow rate duing the on-period as well as the dry-bulb and wet-balb temperature of the air entering and surrounding the unit shall be the same as the high temperature test conditions. The temperature of the entering water of a hot water system shall remain the same as in Test $A$ within the tolerance specified in Section 6.3.4. During the cyclic test, the water flow and the indoor fan cycle 'on' and 'off' as the generator cycles 'on' and 'off', except that the indoor fan cycling times may be delayed due to controls that are normally installed with the unit. The generator cycling times shall be 12 minutes 'on' and 48 minutes 'of f', unless the thermostat supplied by the manufacturer specifies on-off times at $80 \%$ burner on-time that are different. 


\section{3 .5 Summary}

The test requirements for air source and water-source direct-fired heat pump systems are summarized in Table 2. The results of these tests shall be used to calculate system heating capacity and coefficient of performance as well as the seasonal performance factor and seasonal operating cost. Pertinent test data and calculated results shall be reported according to the recommended rating sheets discussed in Section 2.4 and illustrated in Table 6.

\subsection{Suggested Rating Sheets}

Rating sheets for the systems examined in this study are illustrated in Tables 3 and 6 .

Table 3 is applicable to Direct-Fired Absorption Cooling Systems, and requires that the system under test be rated relative to its:

- Steady-state cooling capacity and coefficient of performance at standard (Test A) rating conditions.

- Steady-state cooling capacity and coefficient of performance at Test $B$ and Test $C$ conditions.

- Chilled fluid, condenser unit, and fuel flow rates at rated conditions.

- Coefficient of performance at cyclic Test D.

o On-off times at $20 \%$ barner on time.

- Seasonal performance factor and seasonal operating cost.

Table 6 is applicable to Direct-Fired Absorption Heating Systems, and requires that the system onder test be rated relative to its:

- Steady-state heating capacity and coefficient of performance at standard (Test A) rating conditions.

- Steady-state heating capacity and coefficient of performance at Test $B$ and Test $C$ conditions. 
- Source fluid, evaporator, and fuel flow rates at rated conditions.

- Coefficient of performance at cyclic Test D.

- 0n-off times at $20 \%$ burner on time.

- Seasonal performance factor and seasonal operating cost. 
3. RECOMMENDED TEST PROCEDURE FOR ABSORPTION COOLING SYSTEMS

\subsection{Introdaction}

The parpose of this section is to describe standard test procedares and methods for determining accurate and reliable test data on the performance of prototype and production type direct-fired absorption cooling systems. The cooling capacity of each system shall be directly determined from the results of a primary test, and indirectly determined from a simultaneously conducted heat balance confirming test. The primary test shall be considered valid when the cooling capacity from the confirming test (heat balance) agrees within six percent of the primary test results. The primary test shall be used as a basis for rating the equipment as recommended in Section 2. There feasible, the test procedares have been taken or adapted from ASHRAE Standards (Ref. 10, 11, and 12). ARI Standards (Ref, 9) and ANSI Standards (Ref. 2).

\subsection{Steady-State Test Procedare}

\subsubsection{Applicable Test Method}

The test method most appropriate for determining the steady-state cooling capacity of absorption air-conditioners is the air-enthalpy method. In this method, cooling capacities are determined from measurements of the air flow rate and the wet- and dry-bulb temperatures of the air stream entering and leaving the cooling coil. This method shall be used as the primary test method for absorption air-conditioning equipment covered by this report. When required as part of the confirming test, the air enthalpy method shall also be used to determine the heat rejected by the condenser unit of systems rejecting heat to air. A description of this method and its associated test room and measurement requirements is presented in Section 4 of the ASHRAE Standard (Ref. 10). 
The primary test for determining the cooling capacity of absorption waterchillers shall be the simultaneous measurement of the water flow rate and the temperature difference between entering and leaving chilled water. This method shall also be used in the confirming test to determine the energy rejected by the condenser unit circuit of systems which reject heat to water. For direct-fired systems, the energy inpat to the refrigeration cycle shall be determined from the fuel's steady-state flow rate, its higher heating value and the electric power consumption.

\subsubsection{Instrumentation and Required Data}

The steady-state performance tests shall have the same instrumentation and data requirements as those specified in Section 9 and Table 1 of ASHRAE Standard (Ref. 10). Provision shall be made to determine the cooling capacity of absorption water-chilling systems.

\subsubsection{Test Operating Procedure and Results}

The equipment under test and the test room reconditioning apparatus shall be operated until 'equilibrium conditions' are attained bat not for less than one hour, before any test data is recorded. Data shall then be recorded at 10 minute intervals antil seven consecutive sets of readings ithin the tolerances specified in Section 3.2 .4 are attained.

The steady-state results of a performance test at specified conditions shall include each of the following quantities as are applicable to the equipwent under test:

1) Total cooling capacity, kT (Btu/hr). 
2) Condenser unit heat rejection, kW (Btn/hr).

3) Energy input to the generator, $\mathrm{kT}$ (Btu/hr).

4) Total electric power input to all components and accessories, kWh.

5) Coeficient of performance.

6) F1 ow rate of mediun to be cooled (water for chillers--air for airconditioners), $\mathrm{kg} / \mathrm{hr}$ ( $1 \mathrm{bm} / \mathrm{hr}$. or CFM).

7) Ground water or outside air flow rate over the condenser unit, $\mathrm{kg} / \mathrm{hr}$ $(1 \mathrm{bm} / \mathrm{hr}$ or CFM).

8) Fuel flow rate, $\mathrm{kg} / \mathrm{hr}(1 \mathrm{bm} / \mathrm{hr}$ or CFM).

9) F1 ue gas $\mathrm{CO}_{2}$, \%

10) Flue gas temperature, ${ }^{\circ} \mathrm{C}\left({ }^{\circ} \mathrm{F}\right)$.

11) Surface temperatures of the jacket, ${ }^{\circ} \mathrm{C}\left({ }^{\circ} \mathrm{F}\right)$.

Sections $11.1 .3,11.1 .4$, and 11.2 .1 of the ASHRAE Standard (Ref. 10) sha11 apply for all performance tests.

\subsubsection{Test Tolerances}

All steady-state tests shall be conducted within the tolerances specified in Table II of the ASHRAE Standard (Ref. 10). Test operating tolerance is defined as the greatest permissible difference between marimum and minimum instrument observations during the test. Test condition tolerance is defined as the maximum permissible variation of the average of the test observations from the desired test conditions. Variations greater than those described shall invalidate the test. 


\subsection{Cyc1ic Test Procedure}

\subsubsection{Applicable Test Method}

As outlined in Section 3.2.1 the airenthalpy method shall be ased as a primary test to determine the capacity of absorption air-conditioners. The primary test for determining the capacity of absorption water-chillers shall be the simultaneous measurement of the water flow rate and the temperature difference between inlet and outlet chilled water. For direct-fired systems the energy input to the anit shall be determined from the fuel's flow rate and its higher heating value and the electric power consunption.

\subsubsection{Instrumentation and Required Data}

The cyclic test set ap sha11 have the same instrumentation that is provided for the steady-state tests. In addition, care must be taken to ensare that during the on-time, sufficient data are taken to evaluate capacity and COP with the required accuracy. Usaally this is done by recording the temperature difference between inlet and outlet of the chilled fluid continuously while the fluid flows at a constant rate.

\subsubsection{Test Operating Procedare and Results}

The cyclic performance test, Test $D$, sha11 be performed immediately following Test C. The equipment under test and the test room reconditioning apparatus shall be operated until 'equilibrium conditions' are obtained before any test data are recorded. 'Equilibrium conditions' means in the case of cycling tests that daring subsequent cycles the same set of data within tolerancos specified in Section 3.3.4 during the on and off-period are obtained. Once at 'equilibrium conditions' the data of the subsequent fourth cycle shall be 
recorded. The results of any part load test shall include all quantities 1isted in Section 3.2 .3 except items $2,3,9,10$ and 11.

3.3.4 Test Tolerances

One minute after start op of the burner the same test tolerances shall be applied as specified in Section 3.2 .4 . 
4. MODEL LOADS AND CLIMATE SPECIFICATIONS FOR ABSORPTION COOLING SYSTEMS

\subsection{Introduction}

The seasonal performance and seasonal cost of operation of any direct-fired absorption cooling system depends not only upon the instantaneous performance of the system under specific indoor and outdoor conditions, but also upon the type of building in which it is installed, its thermal 1oad, and the climate in which the building is situated. Because of the wide range of climates in the United States, and the even wider range of building types and thermal requirements, it becomes extremely difficult to adequately characterize the performance of a cooling system in all regions of the country with one or two seasonal indicators. In order to provide the manfacturer of direct-fired equipment some latitude and flexibility in establishing the seasonal performance of his product, two separate evaluation approaches are recommended for seasonal calculations of such systems:

1) The generalized climate of the United States shall be adopted using the average cooling load hours, CLH, determined for the climate. (Table 4).

2) Assuming a more localized climate, the Fractional Temperature Bin Hours and Cooling Load Hours for that climate shall be used. (Generally available Air Force Manual 88-29 and Table 5.)

In both cases, the assumed Outdoor Design Cooling Temperature and Ground Water Temperature shall be $35^{\circ} \mathrm{C}\left(95^{\circ} \mathrm{F}\right)$ and $15.6^{\circ} \mathrm{C}\left(60^{\circ} \mathrm{F}\right)$, respectively. The temperature bin method illustrated in Section 5.6 shall be used to determine the seasonal performance factor and the seasonal operating cost based upon the appropriate climate. 


\subsection{Building Loads}

Cooling requirements are determined by assuming a linear relationship between building load and outdoor dry-bulb temperature. The cooling load line extends from zero load at a specified outdoor temperature $T_{c}$, to a value that is $10 \%$ below the steadystate cooling capacity at an outdoor design

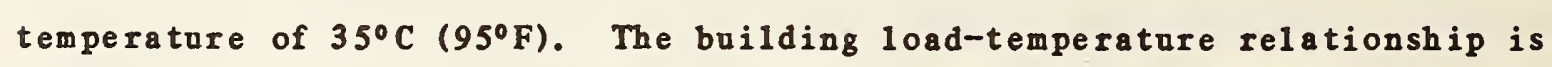
given by:

$$
\operatorname{BL}\left(T_{j}\right)=\frac{\dot{Q}_{s s}\left(T_{h}\right)(5 j-3)}{1.1\left(T_{h}-T_{c}\right)} ; T_{j}>T_{c} \quad \begin{aligned}
& \text { (Temperatures in }{ }^{\circ} F \\
& \text { check equivalent units } \\
& \text { for } \left.{ }^{\circ} \mathrm{C}\right)
\end{aligned}
$$

where $j=1,2, \ldots . n . Q_{S S}\left(T_{h}\right)$ is the measured steady-state cooling capacity of the direct-fired absorption system at the assumed design temperature, n represents the total number of non-zero temperature bins, and 1.1 represents an arbitrary oversizing factor. $T_{j}$ is the representative temperature of the $j$ th bin and is given by:

$$
T_{j}=T_{c}-3+5 j \quad ; \quad T_{j}>T_{c}
$$

The change-over temperature $T_{c}$ is assumed to be $18.3^{\circ} \mathrm{C}\left(65^{\circ} \mathrm{F}\right)$.

The fractional building cooling load at a representative ontdoor temperature, $T_{j}$, is expressed as:

$$
B L\left(T_{j}\right) \cdot \frac{n_{i}}{N}=\frac{Q_{s S}\left(T_{h}\right)\left(5_{j}-3\right)}{1.1\left(T_{h}-T_{c}\right)} \cdot \frac{n_{i}}{N}
$$


where $n_{j} / N$ is the ratio of bin hours of the $j$ th temperatare bins to the total seasonal cooling hours. 
5. CALCULATION PROCEDURE FOR ABSORPTION COOLING SYSTEMS

\subsection{Introduction}

The calcalation procedure in this section describes methods for calculating cooling capacity, condenser unit heat flow, inpot energy to the generator, electric power consumption, and coefficient of performance of all the absorption cooling systems considered in this study. In addition, a procedure is defined for calculating the seasonal performance factor and seasonal operating cost of direct-fired units rejecting heat to air and direct-fired units which reject heat to ground water.

\subsection{Calculation Procedure for Steady-State Tests}

\subsubsection{Fuel Energy Input}

The rate of thermal energy $\dot{Q}_{g}$ supplied to the generator of direct-fired systems under steady-state conditions is:

$$
\dot{Q}_{g}=\left[\dot{m}_{f} \cdot H H V\right]
$$

where in $f$ is the fuel mass flow rate and HHV is the higher heating value of the fuel on a mas basis.

\subsubsection{Electrical Energy Input}

The total electrical power input to the unit is defined by:

$$
\mathbf{P}_{t}=\mathbf{P}_{\mathrm{e}}+\mathbf{P}_{\mathrm{c}}+\mathbf{P}_{\mathrm{aux}}
$$

where $P_{t}$ is the total amount of electrical power being supplied averaged over the test duration. For water chillers $P_{e}$ is the power to the chilled water pump. If this pump is not furnished with the nnit, a value of 11.4 watts/kW 
(40 watts/ton) shall be assumed. For air-conditioners $P_{e}$ is the power of the indoor fan. If a $f a n$ is not furnished as part of the mode1, a value of 0.777 W per //sec (1250 Btu/hr per $1000 \mathrm{cfm})$ shall be assumed. In the case of units which reject heat to water $P_{c}$ is the power to the condenser water pum. If this pump is not furnished with the onit, a value of 20 watts/kW (70 watts/ton) shall be assumed. For units which reject heat to outdoor air $P_{c}$ is the power to the outdoor fan. $P_{a u x}$ is the electrical power required by the various controls and axilliaries.

\subsubsection{Cooling Capacity}

The steady-state cooling capacity $\dot{Q}_{s s}$ of absorption air-conditioners shall be determined according to the air-enthalpy method outlined in Section 4 of ASHRAE Standard (Ref. 10) using the appropriate equations specified in Section 4.6 and 7.4. For air-conditioning systems which may wot have indoor-air circulating fans furnished as part of the system, their measured cooling capacity shail be adjusted by subtracting $0.777 \mathrm{~W}$ per $/ / \mathrm{sec}(1250 \mathrm{Btu} / \mathrm{hr}$ per $1000 \mathrm{cfm}$ ) of indoor airflow from the measured value.

For water chillers, the steady-state cooling capacity shall be determined from

$$
\dot{Q}_{s S}=\dot{m}_{e} c_{p}\left(T_{e 1}-T_{e 2}\right)
$$

where $\dot{m}_{e}$ is the water mass $f 10$ rate through the cooling coils and $T_{e 1}$ and $T_{e 2}$ are the cooling coil inlet and outlet water temperatares, respectively.

It is assumed that the effect of the chilled water circulation pamp on the capacity is negligible. 


\subsubsection{Heat Balance - Confirming Test}

This method is used to confirm the direct measurement of steady-state cooling capacity by algebraically combining the measured values of generator input energy $\dot{Q}_{g}$, condensing anit heat $\dot{Q}_{c}$ (includes both condenser and absorber heats), and the total electrical energy $P_{t}$ input to the unit. Accordingly the steady-state cooling capacity by the heat balance method is:

$$
\dot{Q}_{s s}=\dot{Q}_{c}-\dot{Q}_{g}-3.413 \cdot P_{t}+\dot{Q}_{j}+\dot{Q}_{f}
$$

where the $\dot{Q}$ 's are measured in $B t a / h r$ and $P_{t}$ in watts.

$\dot{Q}_{g}$ is discussed in Section 5.2.1. $\dot{Q}_{f}$ is the residual energy in the products of combustion (flue gas) leaving the system, and is determined from measurement of flue gas temperature and $\mathrm{CO}_{2}$ content. $\dot{Q}_{j}$ is jacket heat loss and represents the convective and radiative losses from heated metal surfaces. Its determination is based npon appropriate surface temperature readings and calculation methods presented in Appendix B of reference (2). The jacket surface temperature measurement is performed in the manner described in part 2.12 of reference (7).

$Q_{c}$ represents the amount of energy rejected from the refrigeration machine including energy added to the cooling fluid from fans or pums.

For units rejecting heat to air the heat rejection shall be calculated from:

$$
\begin{aligned}
\dot{Q}_{c}=1.08 \dot{Q}_{s c}\left(T_{c 2}-T_{c 1}\right) \quad & \text { (Temperatures in }{ }^{\circ} F, \dot{Q}_{s c} \text { in } \\
& \text { CFM; check equivalent units } \\
& \text { for } \left.{ }^{\circ} \mathrm{C}\right) .
\end{aligned}
$$


where $Q_{c}$ is in Bta/hr.

$\dot{Q}_{s c}$ is the air flow rate across the condenser and absorber coils (in some units it includes the combustion flue gas as well) corrected to standard conditions, and which is calculated from equations specified in Section 7.4 of the ASHRAE Standard (Ref, 10). $T_{c 1}$ and $T_{c 2}$ are the inlet and outlet temperatures of the cooling air respectively.

For those units, where the flue gases are mized, with the condenser unit cooling air, $\dot{Q}_{f}$ is already included in the measured value of $\dot{Q}_{c}$. Therefore, term $Q_{f}$ in equation (5.4) shall be neglected.

For units rejecting heat to water, the heat rejection shall be determined from:

$$
Q_{c}=\dot{m}_{c} c_{p}\left(T_{c 2}-T_{c 1}\right)
$$

where $\dot{m}_{c}$ is the mass f1ow Iate of the cooling water and $T_{c 1}$ and $T_{c 2}$ are the inlet and outlet temperatures of the cooling rater, respectively, and $C_{p}$ is the specific heat (1iquid) of the water.

\subsection{Calculation Procedure for Cyclic Tests}

Since the cooling capacity varies with the unit on-time the cooling done over a complete cycle for water chillers is evaluated by:

$$
Q_{c y c}=\dot{m}_{e} C_{p} \int_{t_{\text {pump on }}}^{t_{\text {pump of } f}} \Delta T(t) d t
$$


$\dot{Q}_{\text {cyc }}$ is the cooling done over a complete cycle, $\dot{m}_{e}$ is the flow rate of the chilled water, assumed to be constant with time, $\Delta T$ is the temperature difference which is a function of time $(t)$ and $t_{p o m p}$ on is the on-time of the chilled water pump over a complete cycle.

For air-conditioners the following equation should be used to determine cyclic cooling done.

$$
Q_{c y c}=\frac{60 \dot{V} c_{p a}}{v_{n}\left(1+W_{n}\right)} \int_{t_{f a n \text { on }}}^{t_{f a n ~ o f f}} \Delta T(t) d t
$$

$\forall$ is the air flow rate (which is assumed to be constant), $C_{p a}$ is the specific heat at constant pressure of the air-water mixture per pound of dry air $\left(C_{p a}=\right.$ $\left.1.01+1.86 W_{n}, \mathrm{~kJ} / \mathrm{kg}^{\circ}{ }^{\circ} \mathrm{C},\left[0.24+0.444 W_{n}, \mathrm{Btu} / 1 \mathrm{bm}{ }^{\circ} \mathrm{F}\right]\right)$, and $\mathrm{v}_{\mathrm{n}}$ and $W_{\mathrm{n}}$ are the specific volume and humidity ratio of the air-water mirture at the position where the flow rate measurements are taken. $\Delta T$ is the temperature difference which is a function of time and $t_{\text {fan }}$ on is the on-time of the indoor fan over a complete cycle.

For air-conditioning systems wich may not have indoor air circulating fans furnished as part of the system, their measured cooling capacity shall be adjusted by subtracting $0.777 \mathrm{~W}$ per $\ell / \mathrm{sec}(1250 \mathrm{Btu} / \mathrm{hr}$ per $1000 \mathrm{SCFM})$ of indoor air flow from the measured value. 


\subsection{Coefficient of Performance}

The coefficient of performance for direct-fired systems shall be based on the total fuel energy input to the system plas electrical energy supplied to fans, pumps, controls, etc. Accordingly.

$$
C O P_{s s}=\frac{\dot{Q}_{s s}}{\dot{\mathrm{m}}_{\mathrm{f}} \cdot \mathrm{HHV}+3.413 \mathrm{P}_{\mathrm{t}}}
$$

where ( $\left.\dot{m}_{f} \cdot H H V\right)$ is in Bta/hr and $P_{t}$ is in atts; 3.413 is conversion from watts to Bta/hr. $P_{t}$ is the total amount of electrical energy consumed during the test duration as given by equation (5.2).

The COP cyc for Test D shall be evaluated according to equation (5.9) with the following modifications.

$\dot{Q}_{s s}$ is replaced by $\dot{Q}_{c y c}$ (eq. 5.7), $\dot{m}_{f}$ is replaced by the total amount of fuel consumed daring one total cycle and $P_{t}$ is replaced by the total amount of electricity consumed during the entire cycle.

\subsection{Seasona 1 Performance Factor and Seasonal Operating Costs}

This section describes a calculation procedure for determining the seasonal performance factor (SPF) and seasonal operating costs (SOC) of direct-fired absorption cooling systems.

The fractional energy consumption in the jth temperature bin shall be eval uated by: 


$$
E\left(T_{j}\right) \cdot \frac{n_{j}}{N}=\frac{\operatorname{CLF}\left(T_{j}\right)}{1-C_{D}\left(1-\operatorname{CLF}\left(T_{j}\right)\right)} \cdot \dot{E}_{s s} \cdot \frac{n_{j}}{N}
$$

where $\dot{E}_{s s}=\left(\dot{m}_{f} \cdot H H F\right)+3.413 \mathrm{P}_{t}$ and is the steady-state energy input to the unit; it is assumed to be independent of temperature, becanse fuel flow rate and electrical power consumption do not vary significantly with outdoor temperature. The cooling load factor CLF is obtained by the following equation:

$$
\begin{aligned}
& \operatorname{CLF}\left(T_{j}\right)=\frac{B L\left(T_{j}\right)}{Q_{S S}\left(T_{j}\right)} \quad ; \quad \dot{Q}_{s s}\left(T_{j}\right) \geq B L\left(T_{j}\right) \\
& \operatorname{CLF}\left(T_{j}\right)=1 \quad ; \quad \dot{Q}_{S S}\left(T_{j}\right)<B L(T:
\end{aligned}
$$

$Q_{s s}\left(T_{j}\right)$ is evaluated by interpolation or extrapolation of the capacities of Tests $A$ and $B$ according to the following equation:

$$
\dot{Q}_{s s}\left(T_{j}\right)=\dot{Q}_{S s}\left(82^{\circ} \mathrm{F}\right)+a\left(T_{j}-82^{\circ} \mathrm{F}\right)
$$

with $a=\frac{\dot{Q}_{S S}\left(95^{\circ} \mathrm{F}\right)-\dot{Q}_{S S}\left(82^{\circ} \mathrm{F}\right)}{95^{\circ} \mathrm{F}-82^{\circ} \mathrm{F}}$

The degradation factor of equation (5.10) is given by:

$$
C_{D}=\frac{1-\operatorname{PLF}\left(82^{\circ} \mathrm{F}\right)}{1-\operatorname{CLF}\left(82^{\circ} \mathrm{F}\right)}
$$


with $\operatorname{PLF}\left(82^{\circ} \mathrm{F}\right)=\frac{\operatorname{COP}_{\mathrm{cyc}}\left(82^{\circ} \mathrm{F}\right)}{\operatorname{COP}_{\mathrm{SS}}\left(82^{\circ} \mathrm{F}\right)}$

The total amount of energy consumed during an entire season divided by the total number of temperature bin hours, $N$, is evaluated by:

$$
\frac{E}{N}=\sum_{j=1}^{n} E\left(T_{j}\right) \cdot \frac{n_{j}}{N}
$$

where in is the number of non-zero temperature bins. The SPF is then given by:

$$
\mathrm{SPF}=\frac{\mathrm{BL} / \mathrm{N}}{\mathrm{E} / \mathrm{N}}
$$

$$
\text { where } \frac{B L}{N}=\sum_{j=1}^{n} B L\left(T_{j}\right) \cdot \frac{n_{j}}{N}
$$

An estimation of the seasonal operating cost is given by:

$$
\operatorname{SOC}=\frac{E}{N}\left[x C_{f}+(1-x) \frac{C_{e}}{3.413}\right] \cdot \text { CLH }
$$

E is the total energy consumption per season, divided by the total nuber of temperature bin hours, $N, C_{f}$ and $C_{e}$ are the costs for fuel in $\$ / B t a$ and elecricity in $\$ / W h r$ and CLH is the number of total cooling season hours.

Factor $x$ in eq. $(5.17)$ is the ratio of the seasonal primary fael onergy consumption to the total energy consumption. Since this ratio can only be 
approzimated by a few laboratory tests, it is recommended that the cyclic test data ratio of these energies (e.g., the fuel to total) should be used.

The SPF and SOC shal1 be determined from eqs. (5.16) and (5.17) for the climate discussed in Section 4.1. Table 5 is a calculation sheet that may be used for calculating the SPF and SOC for direct-fired absorption systems.

\subsection{Sample Calculations}

The following sample calculations for a chilled water-air heat rejection unit are based on hypothetical data obtained from Tests A, C and D. Test B results are not given as no test is required. The total number of seasonal cooling hours is assumed to be 3825 hours.

Test No.
A: $Q_{S S}\left(95^{\circ} \mathrm{F}\right)=32800 \mathrm{Btu} / \mathrm{hr} \quad \dot{\mathrm{E}}_{S \mathrm{~S}}\left(95^{\circ} \mathrm{F}\right)=81300 \mathrm{Btu} / \mathrm{hr} \quad \mathrm{COP}_{\mathrm{S} \mathrm{S}}\left(95^{\circ} \mathrm{F}\right)=0.403$
$\mathrm{C}: \oint_{\mathrm{S} \mathrm{s}}\left(82^{\circ} \mathrm{F}\right)=36900 \mathrm{Btu} / \mathrm{hr} \quad \mathrm{E}_{S \mathrm{~S}}\left(82^{\circ} \mathrm{F}\right)=81300 \mathrm{Btu} / \mathrm{hr} \quad \operatorname{COP}_{\mathrm{s} \mathrm{s}}\left(82^{\circ} \mathrm{F}\right)=0.454$
$\mathrm{D}: \dot{\mathrm{Q}}_{\mathrm{cyc}}\left(82^{\circ} \mathrm{F}\right)=33415 \mathrm{Btu} / \mathrm{hr} \quad \dot{\mathrm{E}}_{\text {cyc }}\left(82^{\circ} \mathrm{F}\right)=81300 \mathrm{Bta} / \mathrm{hr} \quad \mathrm{COP}_{\text {cyc }}\left(82^{\circ} \mathrm{F}\right)=0.411$

The fractional building load for a given temperature bin is evaluated according to equation $(4.1 \mathrm{a})$. For the first bin temperature at $19.4^{\circ} \mathrm{C}\left(67^{\circ} \mathrm{F}\right)$ :

$$
\mathrm{BL} \cdot \frac{\mathrm{n}_{1}}{\mathrm{~N}}=\frac{32800 \mathrm{Bta} / \mathrm{hr} \cdot[(5 \cdot 1)-3]^{\circ} \mathrm{F}}{1.1\left(95^{\circ} \mathrm{F}-65^{\circ} \mathrm{F}\right)} \cdot 0.214=425 \mathrm{Btu} / \mathrm{hr}
$$

The results for all bin temperatures are 1 isted in Table 10 column. The $\operatorname{CLF}\left(T_{j}\right)$ is obtained according to equations (5.11) and (5.12).

For example: 


$$
\begin{gathered}
Q_{s s^{\prime}}\left(67^{\circ} \mathrm{F}\right)=36900 \mathrm{Bta} / \mathrm{hI}+\left[\frac{32800 \mathrm{Bta} / \mathrm{hr}-36900 \mathrm{Bta} / \mathrm{hI}}{95^{\circ} \mathrm{F}-82^{\circ} \mathrm{F}}\right] . \\
\left(65^{\circ} \mathrm{F}-82^{\circ} \mathrm{F}\right)=41631 \mathrm{Bta} / \mathrm{hr}
\end{gathered}
$$

and

$$
\operatorname{CLF}\left(67^{\circ} \mathrm{F}\right)=\frac{32800 \mathrm{Bta} / \mathrm{hr} \cdot\left(67^{\circ} \mathrm{F}-65^{\circ} \mathrm{F}\right)}{1.1\left(95^{\circ} \mathrm{F}-65^{\circ} \mathrm{F}\right)} \cdot \frac{1}{41631 \mathrm{Bta} / \mathrm{hr}}=0.048
$$

Further values of $\operatorname{CLF}\left(T_{j}\right)$ are 1 isted in column $E$ of Table 10. The energy consumption $E\left(T_{j}\right) \cdot n_{j} / N$ is obtained by applying equations (5.10), (5.13), and (5.14):

$$
\begin{aligned}
& \text { PLF }=\frac{0.411}{0.454}=0.905 \\
& C_{D}=\frac{1-0.905}{1-0.458}=0.175 \\
& E\left(67^{\circ} \mathrm{F}\right) \cdot \frac{n_{j}}{N}=\frac{0.048}{1-0.175(1-0.048)} \cdot 81300 \mathrm{Btu} / \mathrm{hr} \cdot 0.214=1002 \mathrm{Btr} / \mathrm{hr}
\end{aligned}
$$

The results for other temperature bins are again listed in Table 10 colum $F$.

The SPF is then calculated by equation (5.16):

$$
S P F=\frac{11717}{28502}=0.41
$$

According to equation (5.17) the seasonal operating cost, assuing 
$C_{f}=0.005 \frac{\$}{\mathrm{kBta}}$ and $C_{e}=0.06 \frac{\$}{\mathrm{kTh}}$ and $x=0.95$ and $\mathrm{CLH}=3825$

$$
\text { SOC }=28502\left[.95(.005)+.05\left(\frac{.06}{3.413}\right)\right] 3825=\$ 613.67
$$

where it is assumed that the cyclic test data showed that $95 \%$ (i.e., I $=0.95$ )

of the total energy input is fuel.

Example calculations for an airconditioning unit would be similar to those for the vapor compression air-conditioners as illostrated in ASHRAE Standard (Ref. 12). 
6. RECOMMENDED TEST PROCEDURE FOR ABSORPTION HEATING SISTEMS

\subsection{Introduction}

The purpose of this section is to describe standard test procedares and methods for determining accurate and reliable test data on the performance of prototype and production type direct-fired absorption heating systems. The heating capacity of each system shall be directly determined from the results of a primary test, and indirectly determined from a simultaneously conducted heat balance confirming test. The primary test shall be considered valid when the heating capacity from the confirming test (heat balance) agrees within sir percent of the primary test results. The primary test shall be used as a basis for rating the equipment as recommended in Section 2 . Where feasible, the test procedures have been taken or adapted from ASHRAE Standards (Ref. 10 and 11).

\subsection{Steady-State Test Procedure}

\subsubsection{Applicable Test Method}

The test method most appropriate for determining the steady-state heating capacity of absorption heat pumps is the air-enthalpy method--indoor side (for forced air heating systems). In this method, heating capacities are determined from measurements of the air flow rate and the dry bulb temperatures of the airstream entering and leaving the heating coil. This method shall be used as the primary test method for absorption heat pump equipment covered by this report. When required as part of the confirming test, the air enthalpy method shall be used to determine the heat absorbed by the evaporator onit of air source systems. A description of this method and its asociated test room and measurements requirements is presented in Section 3 of ASHRAE Standard (Ref. 11). 
The method nsed as a confirmation test to determine the energy absorbed by the evaporator unit of water-source systems shall be the simultaneous measurement of the water flow sate and the temperature difference between entering and leaving water of the indoor coil.

For direct-fired systems the energy input to the refrigeration cycle shall be determined from the fuel's steady-state flow rate, its higher heating value and the electric power consumption.

\subsubsection{Instrumentation and Required Data}

The steady-state performance tests shall have the same instrumentation and data requirements as those specified in Section 10 and Table II of ASHRAE Standard (Ref. 11). Provision shall be made to determine the heating capacity of absorption heat pump systems.

\subsubsection{Test Operating Procedure and Results}

The equipment under test and the test room reconditioning apparatis shall be operated until equilibrim conditions are attained, but not for less than one honr, before any test data is recorded. Data shall then be recorded at 10 minte intervals until seven consecutive sets of readings within the tolerances specified in Section 6.2 .4 are attained.

The steady-state results of a performance test at specified conditions shall include each of the following quatities as are applicable to the equipment under test:

1) Total heating capacity, 1 (Bta/hr) 
2) Evaporator unit heat absorption, ll (Bta/hr)

3) Energy input to the generator, kW (Bta/hr)

4) Total electric power inpat to all components and accessories, kWh.

5) Coefficient of performance

6) F1 ow rate of medium to be heated (hot water or indoor air), $\mathrm{kg} / \mathrm{hr}$ ( $1 \mathrm{bm} / \mathrm{hr}$ or (FM).

7) Ground water or outside air flow rate over the evaporator nnit, $\mathrm{kg} / \mathrm{hr}$ $(1 \mathrm{bm} / \mathrm{hr}$ or CFM).

8) Fuel flow rate, $\mathrm{kg} / \mathrm{hr}(1 \mathrm{bm} / \mathrm{hr}$ or CFM).

9) F1ue gas $\mathrm{CO}_{2}, \%$

10) Flue gas temperature, ${ }^{\circ} \mathrm{C}\left({ }^{\circ} \mathrm{F}\right)$

11) Surface temperatures of the jacket, ${ }^{\circ} \mathrm{C}\left({ }^{\circ} \mathrm{F}\right)$

Sections $12.15,12.16$, and 15 of the ASHRAE Standard (Ref. 11) shall apply for al1 performance tests.

\subsubsection{Test Tolerances}

Al1 steady-state tests sha11 be conducted within the tolerances specified in Table III of the ASHRAE Standard (Ref. 11). Test operating tolerance is defined as the greatest permissible difference between maximum and minimum instrument observations daring the test. Test condition tolerance is defined as the maximum permissible variation of the average of the test observations from the desired test conditions. Variations greater than those described shall invalidate the test. 


\subsection{Cyclic Test Procedure}

\subsubsection{Applicable Test Method}

As outlined in Section 6.2 .1 the air enthalpy method shall be used as a primary test to determine the capacity of absorption heat pumps. Air-source anits coil must be clean of frost both before and throughout the test daration.

\subsubsection{Instrumentation and Required Data}

The cyclic test set up shall have the same instrumentation that is provided for the steady-state tests. In addition, care must be taken to ensure that during the on-time, sofficient data are taken to evaluate capacity and cop with the required accuracy. Usually this is done by recording the temperature difference betreen inlet and outlet water, circulating through the condensing unit, while the fluid flows at a constant flow rate.

\subsubsection{Test Operating Procedure and Results}

The cyclic performance test, Test D, shall be performed immediately following the high temperature test, Test A. The equipment under test and the test room reconditioning apparatus shall be operated until 'equilibrium conditions' are obtained before any test data are recorded. 'Equilibrium conditions' means in the case of cycling tests that during subsequent cycles the same set of data within tolerances specified in Section 6.3.4 during the on- and off-period are obtained. 'Once at 'equilibrium conditions' the data of the subsequent fourth cycle shall be recorded. The results of any part-load test shall include all quantities 1 isted in Section 6.2 .3 except items 2 and 3 . 
6.3.4 Test Tolerances

One minute after start up of the burner the same test tolerances shall be applied as specified in Section 6.2 .4 .

\subsection{Frost Accumulation Test Procedure}

\subsubsection{Applicable Test Method}

This test is to be conducted solely for air source systems using the method described in Section 6.2.1--Indoor side--as a primary test. A capacity determination based on the indoor air enthalpy measurements is the only permissible test. During this test any apparatus disturbing normal outdoor air flow on the equipment must not be connected. The indoor airflow is to be allowed to continue with no changes in the air flow settings for test equiment or associated test apparatus, except that if the defrost controls provide for stopping the indoor fan, provision shall be made to shat off flow of air through the indoor coil from the test apparatus while the indoor fan is stopped. The same is true for the water flow in a hot water heating system.

\subsubsection{Instrumentation and Required Data}

The frost accumelation performance tests shall have the same instrumentation and data requirements as specified in Section 10 and Table II of ASHRAE Standard (Ref. 11).

\subsubsection{Test Operating Procedure and Results}

The equipment under test and the test room reconditioning apparatus shall be operated for a test period of three hours. If the unit is in defrost at the end of this test period, the cycle shall be completed. Data shall be recorded at normal ten minute intervals (see Section 11.3 .2 of ASHRAE Standard (Ref. 
11), except that during the defrost cycle data shall be recorded continuously to establish accurately the start and completion of the defrost cycle, the time-temperature pattern of the indoor air stream (if the indoor fan is running) and the electrical and fuel input to the equipment.

The results of this performance test at specified conditions shall include all quantities 1 isted in Section 6.2 .3 as are applicable to the air source units.

\subsubsection{Test Tolerances}

All test observations shall be within the tolerances specified in Table III of* the ASHRAE Standard (Ref. 11), as appropriate to the test methods and type of equipment. The maximum permissible variation of any observation during the capacity test is 1 isted under 'Test Operating Tolerance' in the table. This represents the greatest permissible difference between maximum and minimum instrument observations daring the test. The maximum permissible variations of the everage of the test observations from the standard or desired test conditions are shown in the table under 'Test Condition Tolerance'. Variations greater than those described shall invalidate the test. 
7. HODEL LOADS AND CLIMATE SPECIFICATIONS FOR ABSORPTION HEATING SYSTEMS

\subsection{Introduction}

The seasonal performance and seasonal cost of operation of any direct-fired absorption heating system depends not only upon the instantaneous performance of the system under specific indoor and outdoor conditions, but also upon the type of building in wich it is installed, its thermal 1oad, and the climate in which the building is situated. Because of the wide range of climates in the Onited States, and even wider range of building types and thermal requirements, it becomes extremely difficult to adequately characterize the performance of a heating system in all regions of the country with one or two seasonal indicators. In order to provide the manufacturer of direct-fired equipment some latitude and flexibility in establishing the seasonal performance of his product, the following evaluation approach is recommended for seasonal performance calculations of such systems:

For Heating Only Systems -

- Identify climatic region of the United States based on Tables 7 and 8, in which the direct-fired absorption heating system is to be located.

- Use the representative outdoor beating design temperature for this region ( 1 isted in table) to determine the building heating requirement.

- Size the system heating capacity at $80 \%$ of the building heating requirement and use add-on heat (gas furnace or electric resistance heat as appropriate to the unit) to make up the difference.

- Ose the temperature bin method to determine the seasonal performance factor and the seasonal operating cost based upon the appropriate c1 imate.

For Heating and Cooling Systems -

- The system shall be sized based on the cooling load (refer to Section 4.1). 


\subsection{Building Lo8ds}

Heating requirements are determined by assuming a linear relationship between building load and outdoor dry-bulb temperature. The heating $10 a d$ line extends from zero load at a specified change-over temperature, $T_{c}$, to a value that equals the steady-state heating capacity or design heating requirement (whichever is smaller) at the outdoor design temperature, $T_{h}$. The building 1oad-temperature relationship is given by:

$$
\operatorname{BL}\left(T_{j}\right)=\left(\frac{T_{c}-T_{j}}{T_{c}-T_{h}}\right) \cdot(C) \cdot(D H R)
$$

Where $T_{j}$ is the representative temperature of the $j$ th bin and is given by:

$$
T_{j}=T_{c}+2-5_{j} ; T_{j}<T_{c}
$$

The change-over temperature $T_{c}$ is assumed to be $18.3^{\circ} \mathrm{C}\left(65^{\circ} \mathrm{F}\right)$. DHR is the Design Heating Requirement or steady-state heating capacity at $T_{h}$. C is an 'experience factor' which tends to improve the agreement betreen calculated and measured building loads (Ref. 8). The value for $C$ is 0.77 .

The fractional building heating load at a representative outdoor dry-bulb temperature, $T_{j}$, is expressed as:

$$
\operatorname{BL}\left(T_{j}\right) \cdot \frac{n_{j}}{N}=\left[\left(\frac{T_{c}-T_{i}}{T_{c}-T_{h}}\right) \cdot(C) \cdot \quad(D H R)\right] \cdot \frac{n_{i}}{N}
$$

$n_{j} / N$ is the ratio of bin hours of the $j$ th temperature bins to the total seasonal heating hours. 


\section{CALCULATION PROCEDURE FOR ABSORPTION HEATING SYSTEMS}

\subsection{Introduction}

The calculation procedure in this section describes methods for calculating heating capacity, evaporator unit heat flow, input energy to the generator, electric power consumption, and coefficient of performance of all the absorption heating systems considered in this study. In addition, a procedure is defined for calculating the seasonal performance factor and seasonal operating cost of direct-fired air-source systems, and direct-fired water-source systems that absorb heat from ground water.

\subsection{Calculation Procedures for Steady-State Tests}

\subsubsection{Fue1 Energy Input}

The rate of thermal energy $\dot{Q}_{g}$ supplied to the generator of direct-fired systems under steady-state conditions is:

$$
\dot{\mathrm{Q}}_{\mathrm{g}}=\left[\dot{\mathrm{m}}_{\mathrm{f}} \cdot \mathrm{HHV}\right]
$$

where ${ }_{f}$ is the fuel mass 10 rate and HHV is the higher heating value of the fuel on a mas basis.

\subsubsection{Electrical Energy Inpot}

The total electrical power input to the unit is defined by:

$$
\mathbf{P}_{t}=\mathbf{P}_{e}+\mathbf{P}_{c}+\mathbf{P}_{\mathrm{aux}}
$$

where $P_{t}$ is the total amount of electric power being supplied averaged over the test duration. $\mathbb{P}_{e}$ is the power to the supply water pamp. If this pump is not furnished with the unit, a value of 20 watts/kr (70 watts/ton) 
shall be assumed. $P_{c}$ is the power to the evaporator water pump, for water source nnits. If this pump is not furnished with the unit, value of 11.4 watts/kW (40 watts/ton) shall be assumed. $P_{a n z}$ is the electrical power required by the varions controls and anilliaries. For heat pump systems which may not have indoor air circulating fans furnished as part of the system, the total energy used shall be adjusted by adding $0.777 \mathrm{Wer} / / \mathrm{sec}$ (1250 Bta/hr per $1000 \mathrm{cfm}$ ) of indoor air flow.

\subsubsection{Heating Capacity}

The steady-state heating capacity $\dot{Q}_{s s}$ of absorption heat pumps shall be determined according to the air-enthalpy method ontlined in Section 3 of ASHRAE Standard (Ref. 11) using the appropriate equations specified in Section 3.8 and 7.4. For heat pump systems which may not have indoor air-circulating fans furnished as part of the system, their measured heating capacity shall be adjusted by adding $0.777 \mathrm{~W}$ per $\ell / \mathrm{sec}(1250 \mathrm{Bta} / \mathrm{hr}$ per SCFM) of indoor airflow to the measured value.

\subsubsection{Heat Balance - Confirming Test}

This method is used to confirm the direct measurement of steady-state heating capacity by algebraically combining the measured values of generator input energy $\dot{Q}_{g}$, evaporating unit heat absorption $\dot{Q}_{e}$ and the total electrical power power $P_{t}$ input to the anit. Accordingly, the steady-state heating capacity by the heat balance method is:

$$
\dot{Q}_{s s}=\dot{Q}_{e}+\dot{Q}_{g}+3.413 P_{t}-\dot{Q}_{j}-\dot{Q}_{f}
$$

where the $Q^{\prime} s$ are measured in $B t u / h r$ and $P_{t}$ in watts. 
$Q_{g}$ is discussed in Section 5.2.1. $Q_{f}$ is the residual energy in the products of combostion (flue gas) leaving the system, and is determined from measurement of flue gas temperature and $\mathrm{CO}_{2}$ content. $\dot{Q}_{j}$ is the jacket loss and represents the convective and radiative losses from heated metal surfaces. Its determination is based upon appropriate surface temperature readings and calculation methods presented in Appendiz B of reference (2). The jacket surface temperature measurement is performed in the manner described in part 2.12 of reference (7).

$Q_{e}$ represents the amount of energy absorbed by the refrigeration machine from either the outside air or ground water source. For air-source systems, the heat absorption shall be calculated from:

$$
\begin{aligned}
\dot{Q}_{e}=1.08 \dot{Q}_{s c}\left(T_{e_{2}}-T_{e_{1}}\right) & \text { (Temperatures in }{ }^{\circ} F, \dot{Q}_{s c} \\
& \text { in CFM; check equivalent } \\
& \text { units for } \left.{ }^{\circ} \mathrm{C}\right)
\end{aligned}
$$

where $Q_{S c}$ is in Bta/hr.

$Q_{S c}$ is the air flow rate across the evaporator coils corrected to standard conditions, and is calculated from equations specified in Section 7.4 of the ASHRAE Standard (Ref. 11). $T_{e_{1}}$ and $T_{e_{2}}$ are the inlet and ontlet temperatures of the air, respectively.

For water-source systems, the heat absorption shall be determined from:

$$
\dot{Q}_{e}=\dot{m}_{e} C_{p}\left(T_{e_{2}}-T_{e_{1}}\right)
$$


where $\dot{m}_{e}$ is the mass flow rate of the source water and $T_{e_{1}}$ and $T_{e_{2}}$ are the inlet and ontlet temperatures of the source water, respectively. $C_{p}$ is the specific heat (liquid) of the source (ground) water.

\subsection{Calcu1ation Procedure for Crelic Test}

Since the heating capacity varies with the unit on-time, the heating done over a complete cycle for a hot water heat system is evaluated by:

$$
\dot{Q}_{c y c}=\dot{m}_{c} c_{p} \int_{t_{p \text { ump on }}}^{t_{\text {pump of }}} \Delta T(t) d t
$$

$Q_{\text {cyc }}$ is the heating done over a complete cycle, $\dot{m}_{c}$ is the flow rate of the supply water, assumed to be constant with time, $\Delta T$ is the temperature differ ence which is a function of time $(t)$ and $t_{p m p}$ on is the on-time $(t)$ of the supply vater pump, over a complete cycle.

For heat pumps in a hot air system the following equation should be used to determine cyclic heating done.

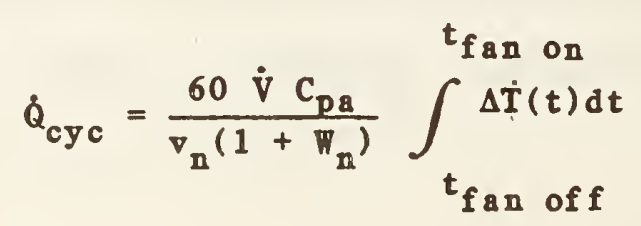

$\forall$ is the air flow rate (which is assumed to be constant), $C_{p a}$ is the specific heat at constant pressure of the air-water mixture per pond of dry air, $C_{p a}=$ $1.01+1.86 W_{n}, \mathrm{~kJ} / \mathrm{kg},{ }^{\circ} \mathrm{C},\left(0.24+0.444 W_{N}, B t a / 1 b m{ }^{\circ} F\right)$, and $\nabla_{n}$ and $W_{n}$ are the specific volume and humidity ratio of the airwater mixture at the same 
position where the flow rate measurements are taken. $\Delta T$ is the temperature difference which is a fuction of time and $t_{\text {fan }}$ on is the on-time of the indoor fan over a complete cycle.

For heating systems which may not have indoor air circulating fans furnished as part of the system, their measured heating capacity shall be adjusted by adding 0.777 per $/ / \sec (1250 \mathrm{Bta} / \mathrm{hr}$ per SCFM) of indoor air flow from the measured value.

\subsection{Coefficient of Performance}

The coefficient of performance for direct-fired systems shall be based on the total fuel energy input to the system plus electrical energy supplied to fans, pumps, controls, etc. Accordingly,

$$
\operatorname{COP}_{s s}=\frac{\dot{Q}_{s s}}{\dot{m}_{f} \cdot H H V+3.413 P_{t}}
$$

where $\left(\dot{m}_{f} \cdot\right.$ HHV) is in Bta/hr and $P_{t}$ in watts; 3.413 is conversion from watts to Btu/hr.

$P_{t}$ is the total cmount of electrical energy consumed during the test duration as given by equation (8.2).

The COP following modifications: 
$\dot{Q}_{s s}$ is replaced by $Q_{\text {cyc }}$ (eq. 8.6), $\dot{m}_{f}$ is replaced by the total amount of fuel consumed during one tot 21 cycle and $P_{t}$ is replaced by the total amount of electricity consumed during the entire cycle.

\subsection{Seasonal Performance Factor and Seasonal Operating Costs}

This section describes a calculation procedure for determining the seasonal performance factor (SPF) and seasonal operating costs (SOC) of direct-fired absorption heating systems.

The fractional energy consumption in the $j$ th temperature bin shall be eval uated by:

$$
E\left(T_{j}\right) \cdot \frac{n_{j}}{N}=\frac{\operatorname{HLF}\left(T_{j}\right)}{1-C_{D}\left(1-\operatorname{HLF}\left(T_{j}\right)\right)} \cdot \dot{E}_{S s} \cdot \frac{n_{j}}{N}
$$

where $\dot{E}_{s s}=\left(\dot{m}_{f} \cdot H H V\right)+3.413 \mathrm{P}_{t}$ and is the steady-state energy input to the unit; it is assumed to be independent of temperature, because fuel flot rate and electrical power consumption do not vary significantly with outdoor temperatare. The hesting load factor, HLF, is obtained by the following equation:

$$
\begin{array}{ll}
\operatorname{HLF}\left(T_{j}\right)=\frac{B L\left(T_{j}\right)}{\dot{Q}_{\delta s}\left(T_{j}\right)} ; & B L\left(T_{j}\right) \leq \dot{Q}_{\delta s}\left(T_{j}\right) \\
\operatorname{HLF}\left(T_{j}\right)=1 \quad ; & B L\left(T_{j}\right)>\dot{Q}_{\delta s}\left(T_{j}\right)
\end{array}
$$

$\dot{Q}_{s s}\left(T_{j}\right)$ is evaluated by interpolation or extrapolation of the capacities of Tests $A$ and $C$ according to the following equation: 


$$
Q_{S s}\left(T_{j}\right)=Q_{S s}\left(47^{\circ} \mathrm{F}\right)+a\left(T_{j}-47^{\circ} \mathrm{F}\right)
$$

withe $=\frac{\dot{Q}_{S S}\left(17^{\circ} \mathrm{F}\right)-\dot{Q}_{S S}\left(47^{\circ} \mathrm{F}\right)}{17^{\circ} \mathrm{F}-47^{\circ} \mathrm{F}}$

The degradation factor of equation (8.9) is given by:

$$
C_{D}=\frac{1-\operatorname{PLF}\left(47^{\circ} \mathrm{F}\right)}{1-\operatorname{HLF}\left(47^{\circ} \mathrm{F}\right)}
$$

With $\operatorname{PLF}\left(47^{\circ} \mathrm{F}\right)=\frac{\operatorname{COP}_{\mathrm{cyc}}\left(47^{\circ} \mathrm{F}\right)}{\operatorname{COP}_{S s}\left(47^{\circ} \mathrm{F}\right)}$

The total amount of energy consumed during an entire season divided by the total number of temperature bin hours, $N$, is evaluated by:

$$
\frac{E}{N}=\sum_{j=1}^{n} E\left(T_{j}\right) \cdot \frac{n_{j}}{N}
$$

where $n$ is the number of non-zero temperature bins. The SPF is then given by:

$$
\mathrm{SPC}=\frac{\mathrm{BL} / \mathrm{N}}{\mathrm{E} / \mathrm{N}+(\mathrm{RH} \cdot 3.413)}
$$

where $\frac{B L}{N}=\sum_{j=1}^{n} B L\left(T_{j}\right) \cdot \frac{n_{j}}{N}$

"If unit is gas-fired use $\left[\dot{m}_{f} \cdot\right.$ HHV $]$. 
and

$$
R H=\sum_{j=1}^{n} \frac{R H\left(T_{j}\right)}{N}=\sum_{j=1}^{n} \frac{\left(B L\left(T_{j}\right)-\dot{Q}_{S S}\left(T_{j}\right)\right)}{3.413} \cdot \frac{n_{i}}{N}
$$

where $B L\left(T_{j}\right) \geq \dot{Q}_{s s}\left(T_{j}\right)$

An estimation of the seasonal operating cost is given by:

$$
\operatorname{SOC}=\frac{E}{N}\left[I C_{f}+(1-x) \frac{C e}{3.413}\right] \cdot \text { BLH }+[R H \cdot 3.413] * \text { HLH }
$$

$E / N$ is the total energy consumption divided by the total number of temperatare bin hours, $N$, per season, $C_{f}$ and $C_{e}$ are the costs for fuel in \$/Bta and electricity in $\$ / T h$ and HLH is the number of total heating season hours. Factor $x$ in equation $(8.16)$ is the ratio of the seasonal primary fuel energy consmption to the total energy consumption. Since this ratio can only be approximated by a fer laboratory tests, it is recommended that the cyclic test data ratio of these energies (e.g., the fuel to total) should be used.

Table 5 is a calculation sheet that may be used for calculating the SPF and SOC for direct-fired absorption systems.

\subsection{Sample Calculations}

The following sample calculations for an airsource hot-water absorption heat pamp anit are based on hypothetical data obtained from Tests A, C and D. The frost accumalation test (Test B) is not being considered in this example.

- If anit is gas-fired use $\left[\dot{m}_{f} \cdot\right.$ HHV $]$. 
We are assuming a location in Maine, which is Region V. The heating load hours and outdoor design temperature corresponding to this region are obtained from Table 7 .

Test No.
$\mathrm{A}: Q_{S S}\left(47^{\circ} \mathrm{F}\right)=52901 \mathrm{Btu} / \mathrm{hr} \quad \mathrm{E}_{S S}\left(47^{\circ} \mathrm{F}\right)=61365 \mathrm{Btu} / \mathrm{hr} \quad \mathrm{COP}_{\mathrm{SS}}\left(47^{\circ} \mathrm{F}\right)=1.16$
$\mathrm{C}: \dot{Q}_{\mathrm{SS}}\left(17^{\circ} \mathrm{F}\right)=46075 \mathrm{Bta} / \mathrm{hr} \quad \dot{\mathrm{E}}_{\mathrm{SS}}\left(17^{\circ} \mathrm{F}\right)=43771 \mathrm{Bta} / \mathrm{hr} \quad \operatorname{COP}_{\mathrm{SS}}\left(17^{\circ} \mathrm{F}\right)=0.95$
$D: \dot{Q}_{c y c}\left(47^{\circ} \mathrm{F}\right)=35000 \mathrm{Bta} / \mathrm{hr} \quad \dot{\mathrm{E}}_{\mathrm{cyc}}\left(47^{\circ} \mathrm{F}\right)=25550 \mathrm{Bta} / \mathrm{hr} \quad \operatorname{coP}_{\mathrm{cyc}}\left(47^{\circ} \mathrm{F}\right)=0.73$

BLH $=2750$ hours $\quad \mathrm{T}_{\mathrm{OD}}=\mathrm{T}_{\mathrm{h}}=-23.3^{\circ} \mathrm{C}\left(-10^{\circ} \mathrm{F}\right)$

The fractional building load for a given temperature bin is evaluated according to equation (7.1a). For the first bin temperature at $16.7^{\circ} \mathrm{C}\left(62^{\circ} \mathrm{F}\right)$.

$\mathrm{BL} \cdot \frac{\mathrm{n}_{1}}{\mathrm{~N}}\left[\left(\frac{65^{\circ} \mathrm{F}-62^{\circ} \mathrm{F}}{65^{\circ} \mathrm{F}-\left(-10^{\circ} \mathrm{F}\right)}\right) \cdot(0.77) \cdot(39932 \mathrm{Btu} / \mathrm{hI})\right] \cdot 0.106=130.4 \mathrm{Btu} / \mathrm{hI}$

where $\mathrm{DHR}=\dot{Q}_{S \mathrm{~S}}\left(-10^{\circ} \mathrm{F}\right)=52901 \mathrm{Btu} / \mathrm{hr}+\left[\frac{46075 \mathrm{Btu} / \mathrm{hr}-52901 \mathrm{Btu} / \mathrm{hr}}{17^{\circ} \mathrm{F}-47^{\circ} \mathrm{F}}\right]$.

$$
\left(-10^{\circ} \mathrm{F}-47^{\circ} \mathrm{F}\right)=39932 \mathrm{Btu} / \mathrm{hr}
$$

is determined from equation (8.11).

The results for all bin temperatures are 1 isted in Table 11 colum $D$. The HLF $\left(T_{j}\right)$ is obtained according to equations (8.10) and (8.11). For erample:

$$
\begin{aligned}
\dot{Q}_{S S}\left(62^{\circ} \mathrm{F}\right) & =52901 \mathrm{Bta} / \mathrm{hI}+\left[\frac{46075 \mathrm{Bta} / \mathrm{hr}-52901 \mathrm{Bta} / \mathrm{hI}}{17^{\circ} \mathrm{F}-47^{\circ} \mathrm{F}}\right] \cdot\left(62^{\circ} \mathrm{F}-47^{\circ} \mathrm{F}\right) \\
& =56313.5 \mathrm{Bta} / \mathrm{hr}
\end{aligned}
$$


and

$\operatorname{HLF}\left(62^{\circ} \mathrm{F}\right)=\left[\left(\frac{65^{\circ} \mathrm{F}-62^{\circ} \mathrm{F}}{65^{\circ} \mathrm{F}-\left(-10^{\circ} \mathrm{F}\right)}\right) \cdot(0.77) \cdot(39932 \mathrm{Bta} / \mathrm{hr})\right] \cdot \frac{1}{56313.5 \mathrm{Btu} / \mathrm{hr}}=0.022$

Farther values of HLF $\left(T_{j}\right)$ are listed in column $E$ of Table 11. The energy consumption $E\left(T_{j}\right) \cdot n_{j} / N$ is obtained by applying equations (8.9), (8.12), and $(8.13):$

$$
\begin{aligned}
& \text { PLF }=\frac{0.73}{1.16}=0.63 \\
& C_{D}=\frac{1-0.63}{1-0.14}=0.43
\end{aligned}
$$

$\mathrm{E}\left(62^{\circ} \mathrm{F}\right) \cdot \frac{\mathrm{n}_{\mathrm{j}}}{\mathrm{N}}=\frac{0.022}{1-0.43(1-0.022)} \cdot 61365 \mathrm{Bta} / \mathrm{hr} \cdot 0.106=247.0 \mathrm{Bta} / \mathrm{hr}$

The results for other temperature bins are again 1 isted in Table 11 column F. The SPF is then calculated by equation (8.15):

$$
\mathrm{SPF}=\frac{12155,7}{21727.1}=0.56
$$

According to equation (8.16) the seasonal operating cost, assuming $C_{f}=0.005$ $\$ / \mathrm{kBtu}$ and $\mathrm{C}_{e}=0.06 \$ / \mathrm{K} \mathrm{Wh}$ and $\mathrm{x}=0.96$ and HLF $=2750$ is:

$$
\mathrm{SOC}=21.727\left[.96(.005)+.04 \frac{.06}{3.413}\right] \cdot 2750=\$ 328.81
$$


where it is assumed that the cyclic test data showed that $96 \%$ (i.e., $x=.96$ ) of the total energy input is fuel. 
9. IIMITATIONS OF THE RECOMMENDED TEST AND RATING PROCEDURES

The test requirements described in Section 2 and illustrated in Tables 1-2 assume that the behavior of the particular system can be sufficiently determined with only four test points. As more laboratory and field experience is acquired on the latest absorption systems, the number of test points may have to be increased to adequately describe the system. The rating procedure way then need to be reviewed to verify that it adequately describes field performance.

Additionaliy, the climate specifications outlined in Sections 4 and 7 are sufficiently general to warrant further investigation. While these seasonal rating approaches soffer the inevitable disadvantages associated $\nabla$ ith climate generalization, they do provide a suitable technique for assessing both relative Carnot effect (i.e., the, use of various temperature reservoir differences) and cycling effect of different absorption systems that are designed for the same market and the same general climate.

These limitations indicate a need for further investigation. 


\section{REFERENCES}

1. American Society of Heating. Refrigerating and Air-Conditioning Engineers, Guide and Data Book, Equipment Volume.

2. American National Standard for Gas-Fired Absorption Summer Air Conditioning Appliances, ANSI Z21.40.1. April 19, 1973.

3. Method of Testing, Rating and Estimating the Seasonal Performance of Central Air-Conditioners and Heat Pumps Operating in the Cooling Mode, Kel1y, G. E., and Parken T. H., NBSIR 77-1271, April 1978.

4. Method of Testing, Rating and Estimating the Heating Seasonal Performance of Heat Pumps, Parken, M. H., Ke11y, G. E., and Didion, D. A., NBSIR 802002, April 1980 .

5. Method of Testing, Rating and Estimating the Seasonal Performance of Ground Water Source Heat Pumps, Mulroy, W. J., NBSIR 81-2434, August 1982 .

6. American National Standard for Gas-Fired Central Furnaces, ANSI Z21.471978 .

7. Airconditioning and Refrigeration Institute, Standard for Ground- Tater Source Heat Pumps, ARI 325-83.

8. Recommended Testing and Calculation Procedures for Determining the Seasonal Performance of Residential Central Furnaces and Boilers, Kelly, G., Chi, J., and Kuklewicz, M., NBSIR 78-1543, October 1978.

9. Air-Conditioning and Refrigeration Institute, Standard for Absorption Water Chilling Packages, ARI 560-82.

10. American Society of Heating, Refrigerating and Air-Conditioning Engineers, Methods for Testing for Rating Heat Operated Unitary Air Conditioning Equipment for Cooling. ASHRE 40-80.

11. American Society of Heating, Refrigerating and Air-Conditioning Engineers, Methods of Testing for Rating Unitary Air-Conditioning and Heat Pump Equipment, ASHRAE 37-78.

12. American Society of Heating, Refrigerating and Air-Conditioning Engineers, Methods of Testing for Seasonal Efficiency of Unitary Air Conditioners and Heat Pumps, ASHRAE 116-84.

13. Air-Conditioning and Refrigeration Institute, Standard for Unitary Air Conditioning Equipment, ARI 210-81. 

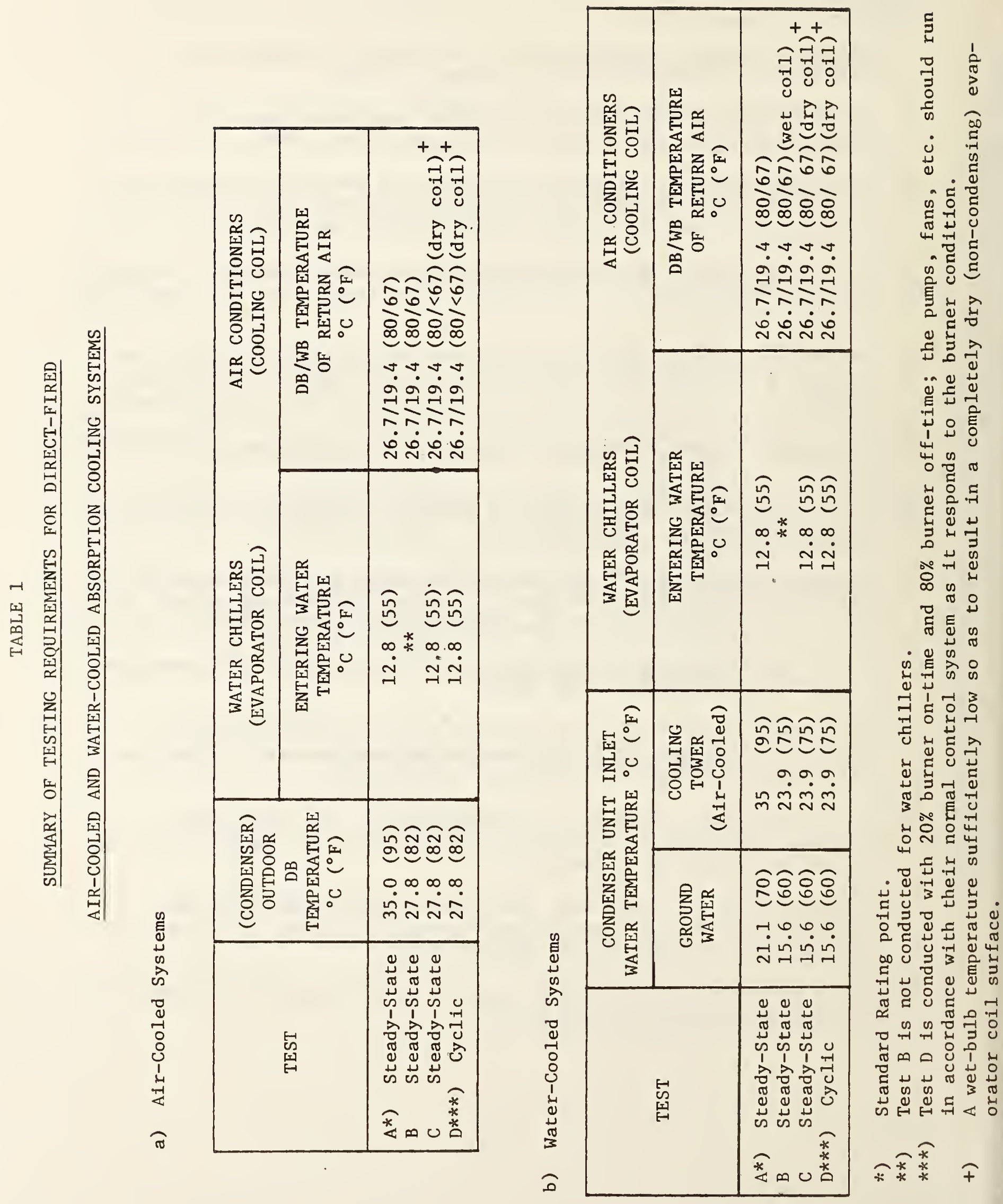
TABLE 2

SUMMARY OF TESTING REQUIREMENTS FOR DIRECT-FIRED AIR-SOURCE AND

WATER-SOURCE ABSORPTION HEATING SYSTEMS

a) Air-Source Systems

\begin{tabular}{|c|c|c|c|c|c|}
\hline \multicolumn{2}{|r|}{ TEST } & \multicolumn{2}{|c|}{$\begin{array}{c}\text { AIR } \\
\text { TEMPERATURE } \\
\text { ENTERING } \\
\text { EVAPORA'TOR } \\
{ }^{\circ} \mathrm{C}\left({ }^{\circ} \mathrm{F}\right)\end{array}$} & $\begin{array}{l}\text { ENTERING WATER } \\
\text { TEMPERATURE } \\
{ }^{\circ} \mathrm{C}\left({ }^{\circ} \mathrm{F}\right)\end{array}$ & $\begin{array}{l}\text { DB/WB TEMPERATURE } \\
\text { OF INDOOR RETURN AIR } \\
{ }^{\circ} \mathrm{C}\left({ }^{\circ} \mathrm{F}\right)\end{array}$ \\
\hline A) & $\begin{array}{l}\text { High-Temperature } \\
\text { (Steady-State) }\end{array}$ & $\mathrm{T}_{\mathrm{WB}}^{\mathrm{T}}$ & $\begin{array}{ll}8.3(47) \\
6.1(43)\end{array}$ & $40.6(105)$ & $21.1(70) /<15.6 \quad(60)$ \\
\hline B) & Frost Accumulation & $\begin{array}{l}\mathrm{T}_{\mathrm{DB}} \\
\mathrm{T}_{\mathrm{DP}}\end{array}$ & $\begin{aligned} 1.7 & (35) \\
-1.1 & (30)\end{aligned}$ & $40.6(105)$ & $21.1(70) /<15.6 \quad(60)$ \\
\hline$C *)$ & $\begin{array}{l}\text { Low Temperature } \\
\text { (Steady-State) }\end{array}$ & $\begin{array}{l}\mathrm{T}_{\mathrm{DB}} \\
\mathrm{T}_{\text {WB }}\end{array}$ & $\begin{array}{l}-8.3(17) \\
-9.4(15)\end{array}$ & $40.6(105)$ & $21.1 \quad(70) /<15.6 \quad(60)$ \\
\hline$D * *)$ & Cyclic & $\mathrm{T}_{\mathrm{WB}}^{\mathrm{T}}$ & $\begin{array}{l}8.3(47) \\
6.1(43)\end{array}$ & $40.6(105)$ & $21.1(70) /<15.6 \quad(60)$ \\
\hline
\end{tabular}

b) Water-Source Systems

\begin{tabular}{|c|c|c|c|c|}
\hline & TEST & $\begin{array}{l}\text { EVAPORATOR INLET } \\
\text { GROUND WATER } \\
{ }^{\circ} \mathrm{C}\left({ }^{\circ} \mathrm{F}\right)\end{array}$ & $\begin{array}{l}\text { HEA } \\
\text { ENTERING WATER } \\
\text { TEMPERATURE } \\
{ }^{\circ} \mathrm{C}\left({ }^{\circ} \mathrm{F}\right)\end{array}$ & $\begin{array}{l}\text { I PUMPS } \\
\text { DB/WB TEMPERATURE } \\
\text { OF INDOOR RETURN AIR } \\
{ }^{\circ} \mathrm{C}\left({ }^{\circ} \mathrm{F}\right)\end{array}$ \\
\hline A) & $\begin{array}{l}\text { High Temperature } \\
\text { (Steady-State) }\end{array}$ & $21.1(70)$ & $40.6(105)$ & $21.1(70) /<15.6(60)$ \\
\hline B) & Frost Accumulation & -- & -- & - \\
\hline$C *)$ & $\begin{array}{l}\text { Low Temperature } \\
\text { (Steady-State) }\end{array}$ & $15.6(60)$ & $40.6(105)$ & $21.1(70) /<15.6 \quad(60)$ \\
\hline$D * \star)$ & Cyclic & $21.1(70)$ & $40.6(105)$ & $21.1(70) /<15.6 \quad(60)$ \\
\hline
\end{tabular}

* Standard Rating Point

** Test $D$ is conducted with $20 \%$ burner on-time and $80 \%$ burner off-time. The entire length of the cycle is determined by the thermostat characteristics supplied by the manufacturer; all pumps, fans, etc. should run in accordance with their normal control system as it responds to the bumer conditions. 
TABLE 3

RATING SHEET FOR DIRECT-FIRED ABSORPTION COOLING SYSTEMS

FUEL:

GAS

$\square$ OIL

$\square$ OTHER

FUEL HIGHER HEATING VALUE: $\mathrm{Btu} / 1 \mathrm{bm}$ or Btu/Ft ${ }^{3}$

FUEL COST: $\$ / k B t u$ COST OF ELECTRICAL POWER: $\$ / k W h$

DESIGN:

$\square$ Single-Effect

.. $\square$ Double Effect

COOLING LOAD HOURS

THERMOSTAT ON-OFF TIME:

TYPE: $\square$ Water Chiller

$\square$ Ground Water Sink

$\square$ Cooling Tower Sink"

$\square$ Outdoor Air Sink $\square$ Air Conditioner

$\square$ Ground Water

Cooling Tower (or water sprayed on outdoor coil)

$\square$ Outdoor Air

REFRIGERANT/ABSORBENT:

\begin{tabular}{|c|c|c|c|c|}
\hline \multirow{2}{*}{ PERFORMANCE PARAMETER } & \multicolumn{4}{|c|}{ TEST } \\
\hline & A & $B * *$ & C & $\mathrm{D}$ \\
\hline $\begin{array}{l}\text { COOLING CAPACITY } \mathrm{kW}(\mathrm{kBtu} / \mathrm{hr}) \\
\text { COEFFICIENT OF PERFORMANCE } \\
\text { FUEL FLOWRATE } \mathrm{kg} / \mathrm{hr}(1 \mathrm{bm} / \mathrm{hr} \text { or CFM)* } \\
\text { POWER CONSUMPTION ( } \mathrm{kWh}) \\
\text { EVAPORATOR (Chilled Fluid) FLOWRATE } \mathrm{kg} / \mathrm{hr}(1 \mathrm{bm} / \mathrm{hr} \text { or CFM)* } \\
\text { CONDENSER UNIT FLOWRATE } \mathrm{kg} / \mathrm{hr}(1 \mathrm{bm} / \mathrm{hr} \text { or CFM) }\end{array}$ & & & & \\
\hline
\end{tabular}

SEASONAL PERFORMANCE FACTOR

SEASONAL OPERATING COST \$

*Flowrates determined at rating conditions.

**Test is not provided for water chillers. 
TABLE 4

FRACTIONAL TEMPERATURE BIN HOURS FOR COOLING SEASON CALCULATION

Fraction of Total

$\begin{array}{ccc}\text { Bin No., } & \text { Bin Temperature, } & \text { Temperature Bin Hours } \\ j & \mathrm{~T}_{j}{ }^{\circ} \mathrm{F} & \mathrm{n}_{\mathrm{j}} / \mathrm{N} \\ 1 & 67 & 0.214 \\ 2 & 72 & 0.231 \\ 3 & 77 & 0.216 \\ 4 & 82 & 0.161 \\ 5 & 87 & 0.104 \\ 6 & 92 & 0.052 \\ 7 & 97 & 0.018 \\ 8 & 102 & 0.004\end{array}$

Cooling Load Hours, CLH - 3825

Outdoor Design Cooling Temperature $-35^{\circ} \mathrm{C}\left(95^{\circ} \mathrm{F}\right)$

Ground Water Temperature $-15.6^{\circ} \mathrm{C}\left(60^{\circ} \mathrm{F}\right)$ 


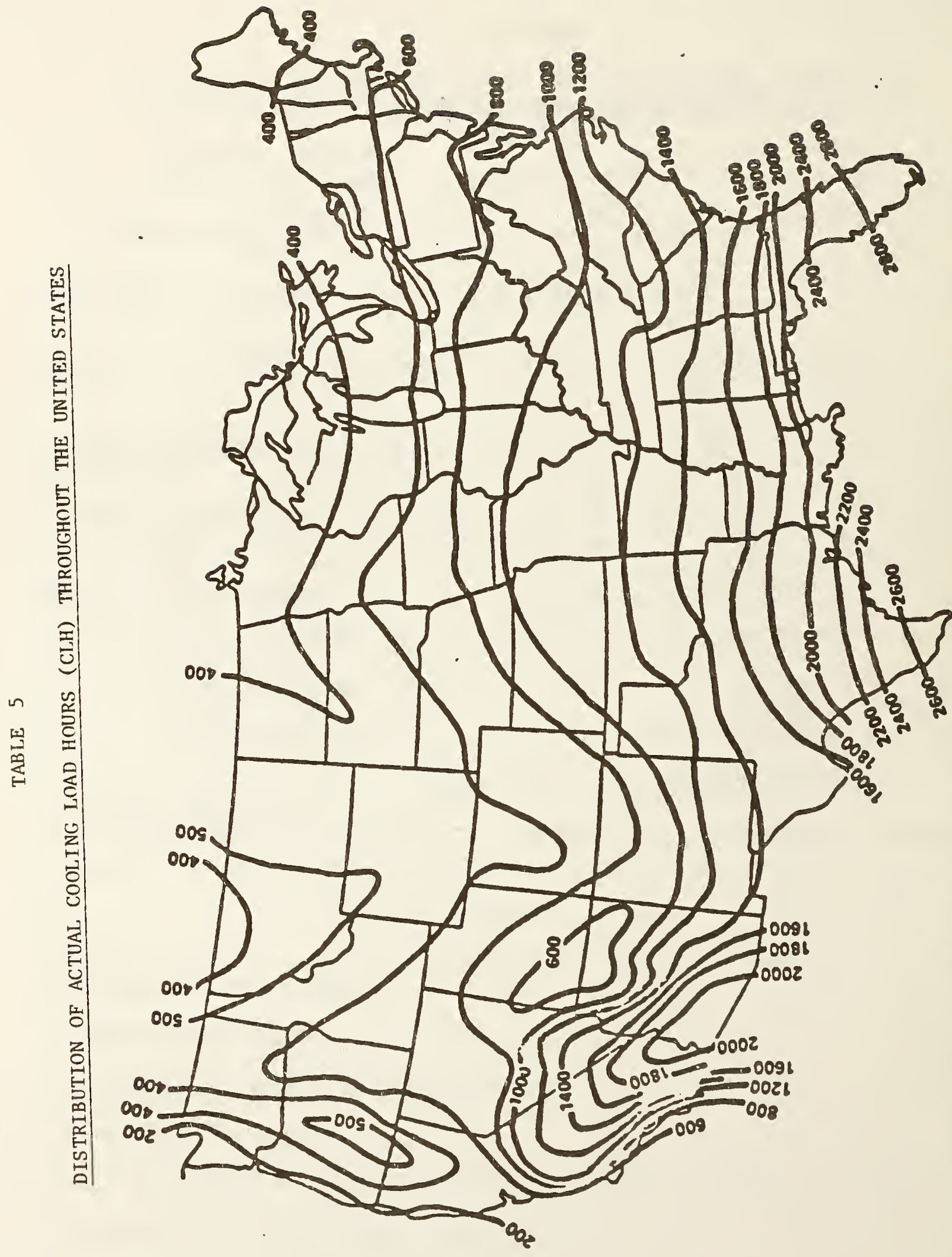

$\frac{5}{2}: 12=8$
$\frac{8}{9}: 128=$
$\frac{8}{8}: 1:=: 8$ 8888888 . 1111110 $8 \frac{8}{5}$ 줄 E

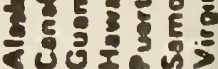


FUEL: $\quad \square$ Gas

$\square$ 0il

Other

FUEL HIGHER HEATING VALUE: $\mathrm{Btu} / \mathrm{lbm}$ or $\mathrm{Btu} / \mathrm{ft}^{3}$

FUEL COST: \$/kBtu COST OF ELECTRICAL POWER: $\$ / k W h$

DESIGN:

$\square$ Single Effect

$\square$ Double Effect

MAJOR CLIMATIC REGION (USA): (See Table 7, 8) THERMOSTAT ON-OFF TIME:

REFRIGERANT/ABSORBENT:

TYPE: $\square$ Hot Air Heat

$\square$ Ground Water Source

$\square$ Outdoor Air Source $\square$ Hot Water Heat

$\square$ Ground Water Source

$\square$ Outdoor Air Source

\begin{tabular}{|l|l|l|l|l|}
\hline \multicolumn{1}{|c|}{ PERFORMANCE PARAMETER } & \multicolumn{3}{|c|}{ TEST } \\
\cline { 2 - 5 } & A & B** & C & D \\
\hline HEATING CAPACITY $\mathrm{kW}(\mathrm{kBtu} / \mathrm{hr})$ & & & & \\
COEFFICIENT OF PERFORMANCE & & & & \\
FUEL FLOWRATE $\mathrm{kg} / \mathrm{hr}(\mathrm{lbm} / \mathrm{hr}$ Or CFM)* & & & & \\
POWER CONSUMPTION (kWh) & & & & \\
EVAPORATOR (SOurCe Fluid) FLOWRATE $\mathrm{kg} / \mathrm{hr}(\mathrm{lbm} / \mathrm{hr}$ or CFM)* & & & & \\
CONDENSER UNIT FLOWRATE $\mathrm{kg} / \mathrm{hr}(\mathrm{lbm} / \mathrm{hr}$ Or CFM) & & & & \\
\hline
\end{tabular}

SEASONAL PERFORMANCE FACTOR

* Flowrates determined at rating conditions.

**Test $B$ is not for water source. 
MAJOR CLIMATIC REGIONS IN THE CONTINENTAL USA

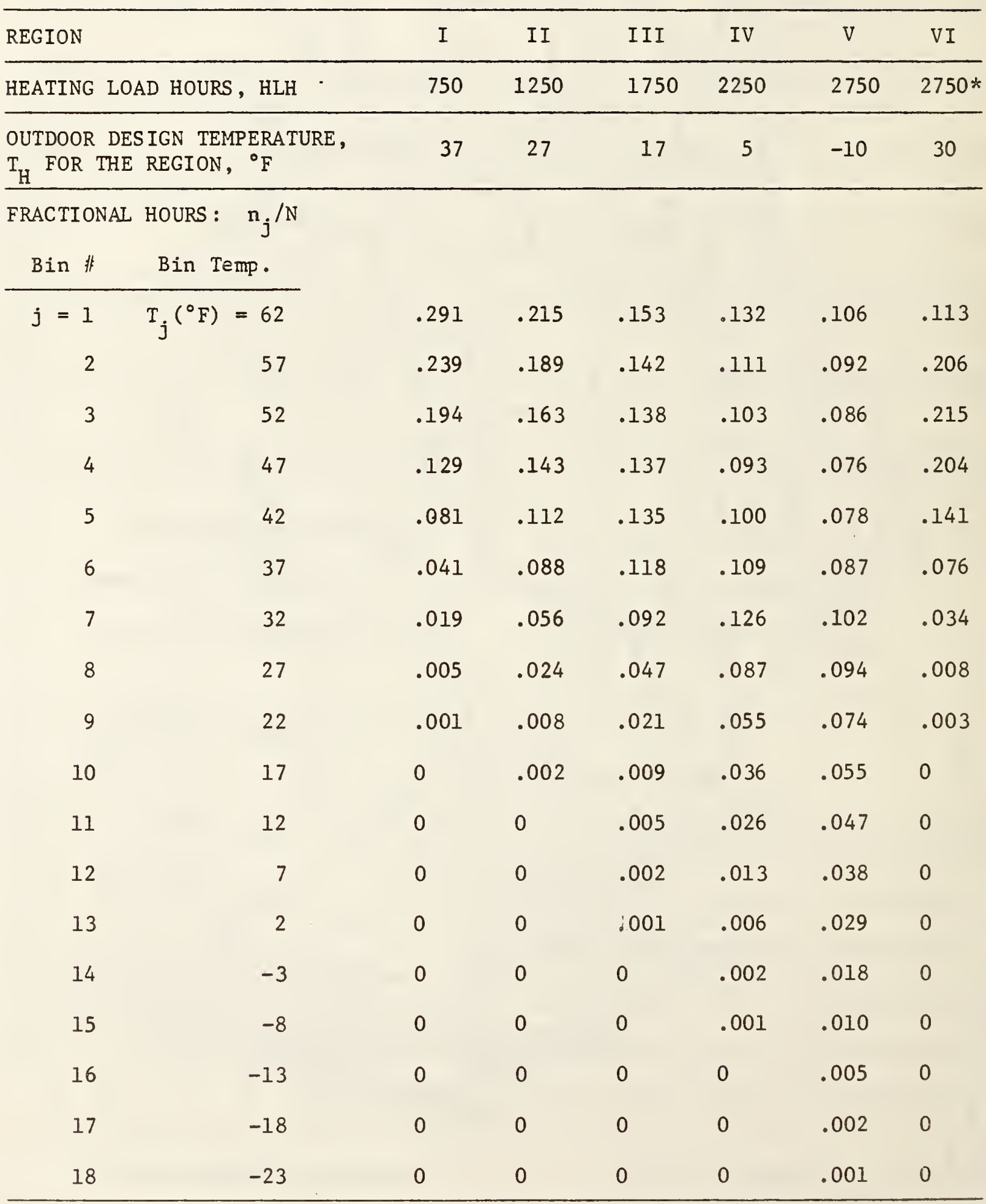




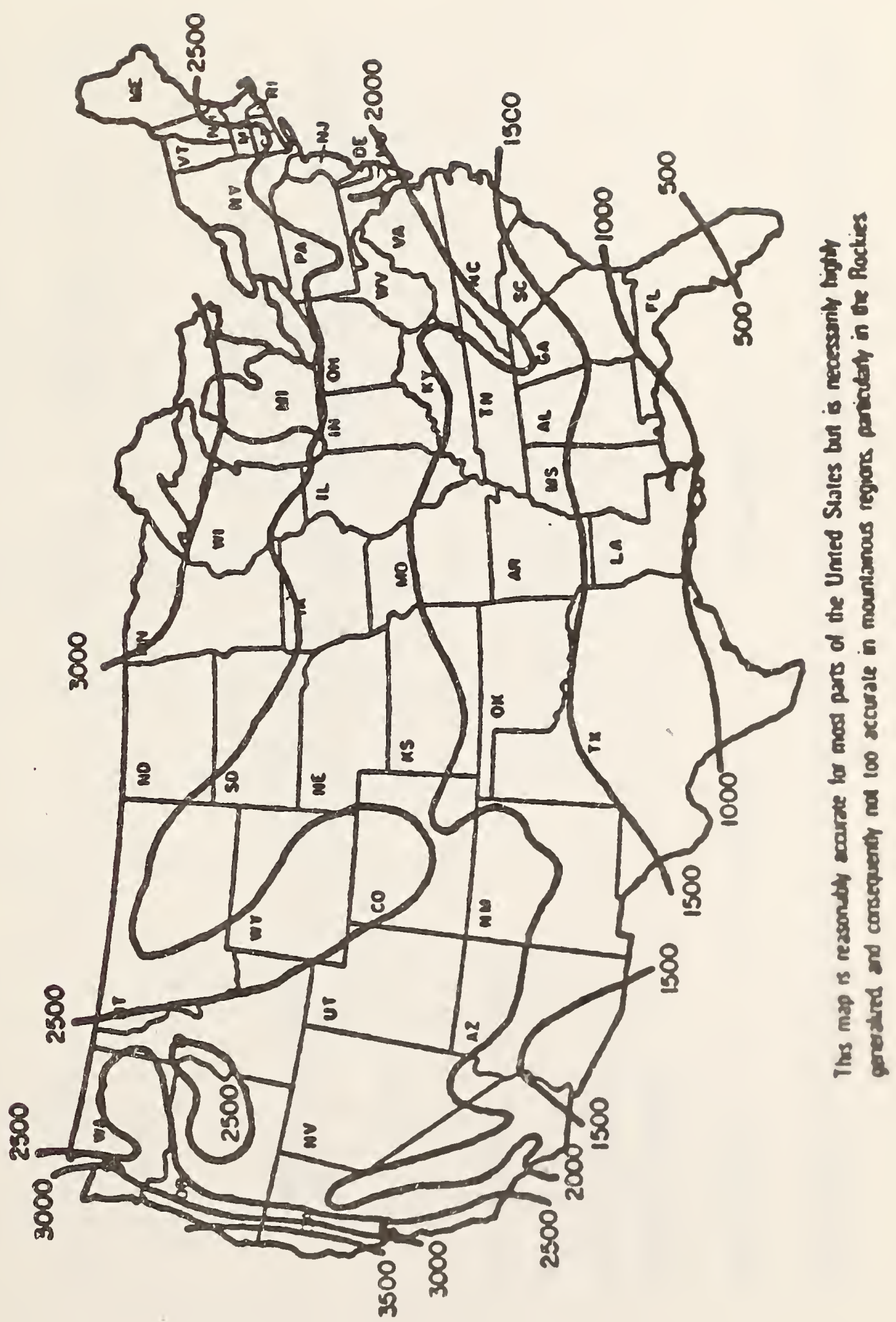




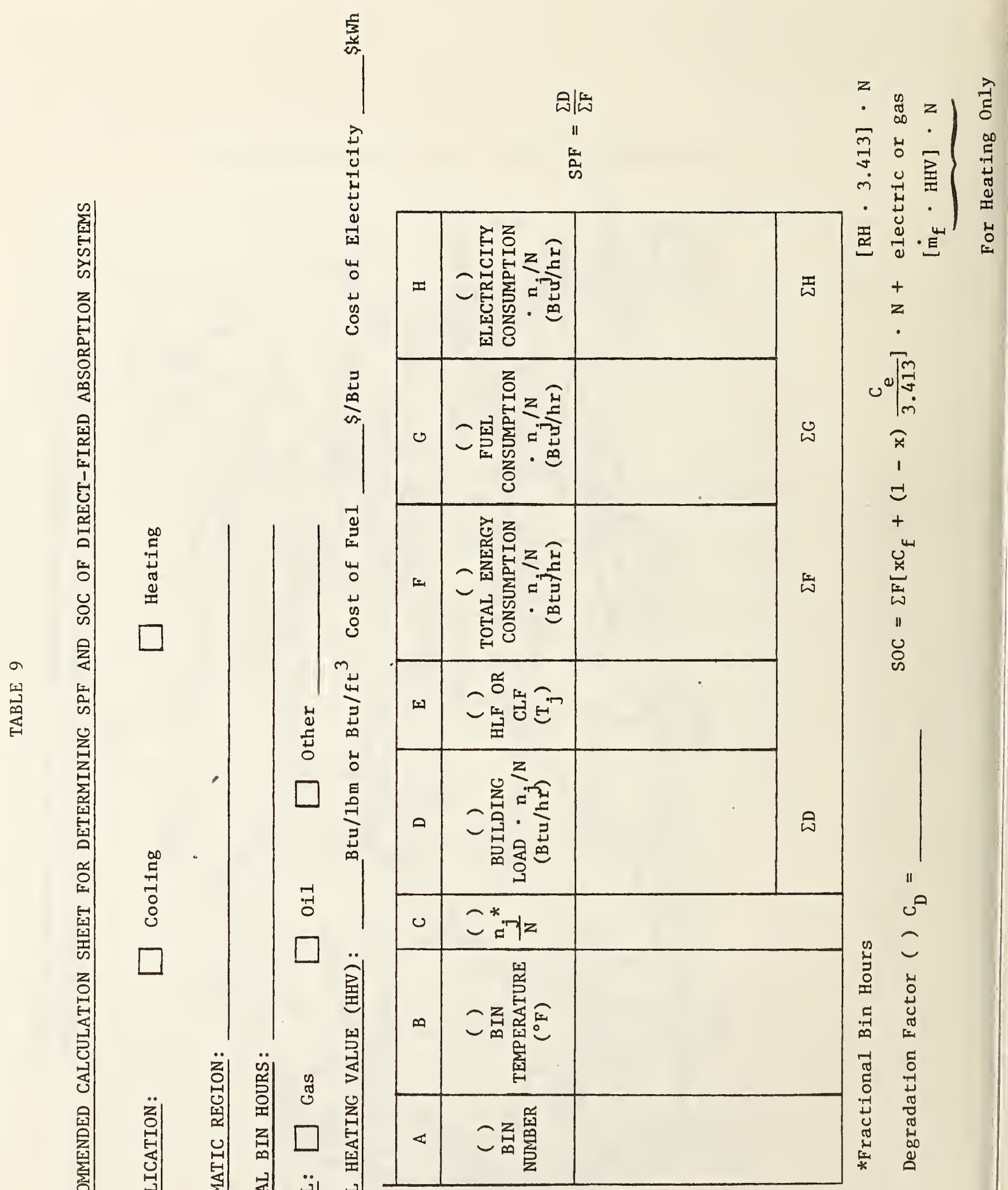




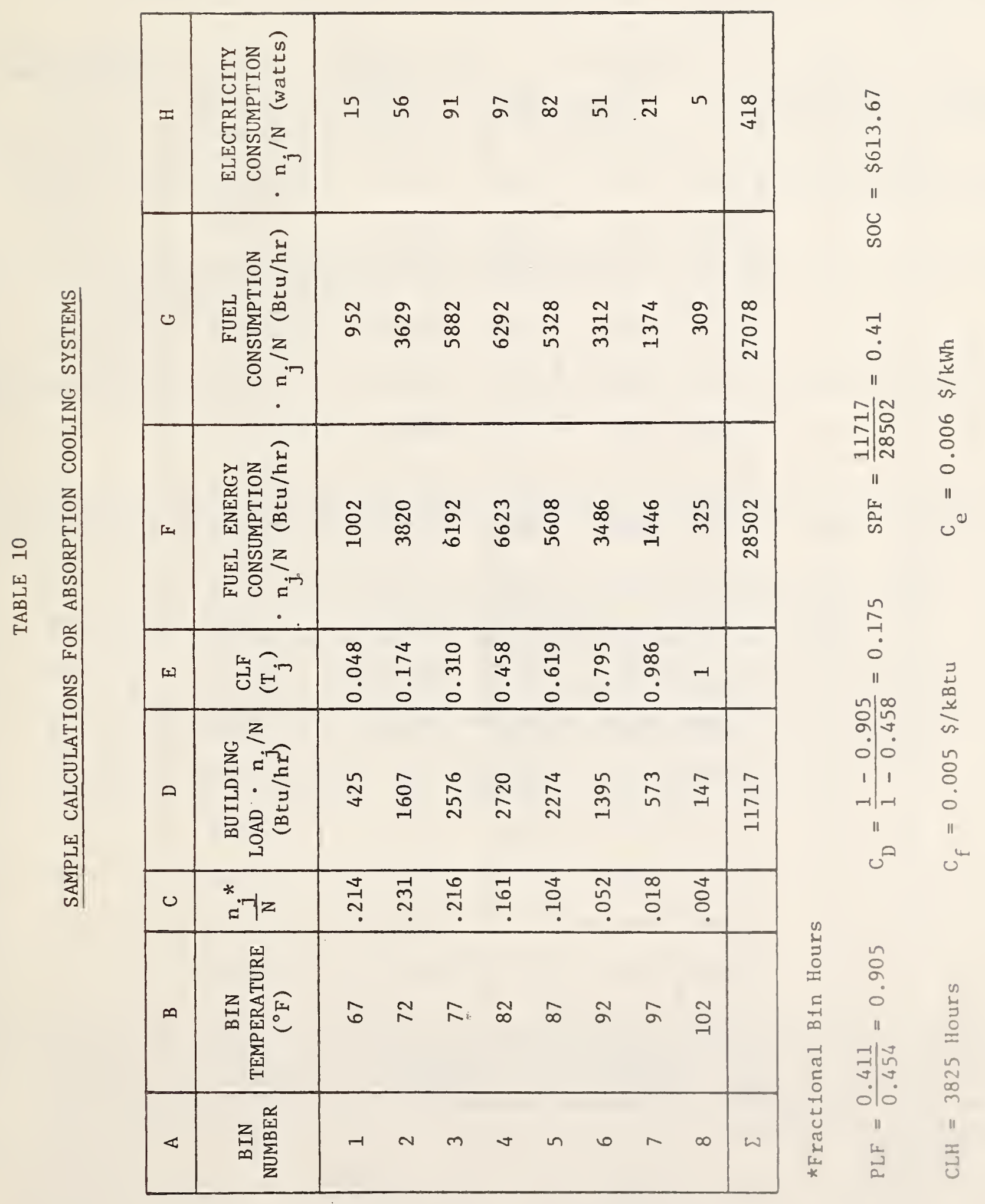




\begin{tabular}{|c|c|c|c|c|c|c|c|}
\hline A & B & C & D & E & F & G & $\mathrm{H}$ \\
\hline $\begin{array}{c}\text { BIN } \\
\text { NUMBER }\end{array}$ & $\begin{array}{c}\text { BIN } \\
\text { TEMPERATURE } \\
\left({ }^{\circ} \mathrm{F}\right)\end{array}$ & $\frac{n_{j}^{*}}{N}$ & $\begin{array}{l}\text { BUILDING } \\
\text { LOAD } \\
\dot{n_{j} / N} \\
(B t u / h r)\end{array}$ & $\begin{array}{l}\text { HLF } \\
\left(T_{j}\right)\end{array}$ & $\begin{array}{c}\text { FUEL ENERGY } \\
\text { CONSUMPTION } \\
\dot{n_{j} / \mathrm{N}} \\
(\mathrm{Btu} / \mathrm{hr})\end{array}$ & $\begin{array}{c}\text { FUEL } \\
\text { CONSUMPTION } \\
\mathrm{n}_{\mathrm{j}} / \mathrm{N} \\
(\mathrm{Btu} / \mathrm{hr})\end{array}$ & $\begin{array}{c}\text { ELECTRICITY } \\
\text { CONSUMPTION } \\
\cdot \mathrm{n}_{\mathrm{j}} / \mathrm{N} \\
\text { (watts) }\end{array}$ \\
\hline 1 & 62 & .106 & 130.4 & .022 & 274.9 & 237.1 & 2.9 \\
\hline 2 & 57 & .092 & 301.7 & .059 & 559.5 & 537.1 & 616 \\
\hline 3 & 52 & .086 & 458.3 & .099 & 852.9 & 818.8 & 10.0 \\
\hline 4 & 47 & .076 & 560.8 & .140 & 1306.1 & 994.7 & 12.1 \\
\hline 5 & 42 & .078 & 735.5 & .182 & 1343.8 & 1290.1 & 15.8 \\
\hline 6 & 37 & .087 & 998.7 & .227 & 1815.3 & 1742.7 & 21.3 \\
\hline 7 & 32 & .102 & 1380.0 & .273 & 2485.9 & 2386.5 & 29.1 \\
\hline 8 & 27 & .094 & 1464.4 & .322 & 2621.7 & 2516.8 & 30.7 \\
\hline 9 & 22 & .074 & 1304.5 & .373 & 2319.0 & 2226.2 & 27.2 \\
\hline 10 & 17 & .055 & 1082.3 & .427 & 1912.3 & 1835.8 & 22.4 \\
\hline 11 & 12 & .047 & 1021.3 & .484 & 1794.0 & 1722.2 & 21.0 \\
\hline 12 & 7 & .038 & 903.6 & .543 & 1575.9 & 1512.9 & 18.5 \\
\hline 13 & 2 & .029 & 749.0 & .605 & 1296.9 & 1245.0 & 15.2 \\
\hline 14 & -2 & .018 & 501.9 & .672 & 864.2 & 829.6 & 10.1 \\
\hline 15 & -7 & .010 & 299.3 & .741 & 511.7 & 491.2 & 6.0 \\
\hline 16 & -13 & .005 & 159.9 & 1 & 306.8 & 294.5 & 3.6 \\
\hline 17 & -18 & .002 & 68.1 & 1 & 122.7 & 117.8 & 1.4 \\
\hline 18 & -23 & .001 & 36.1 & 1 & 61.4 & 58.9 & 0.7 \\
\hline$\Sigma$ & & & 12155.9 & & 21727.1 & 20857.0 & 254.6 \\
\hline
\end{tabular}

*Fractional Bin Hours

PLF $=\frac{0.73}{1.16}=0.63 \quad C_{D}=\frac{1-0.63}{1-0.14}=0.43 \quad S P F=\frac{12155.7}{21727.1}=0.56 \quad$ SOC $=\$ 328.81$ 
NBS-114A, REV V. 2-801

U S. DEPT. OF COMM.

BIBLIOGRAPHIC DATA

SHEET (See instructions)

1. PUBLICATION OR REPORT NO. NBSIR $84-2867$

2. Performing Organ. Report Nof 3. Publication Date

April 1984

4. TITLE AND SUBTITLE

Test Procedures for Rating Residential Heating and Cooling Absorption Equipment

5. $A \cup T H O R(S)$

Brian Weber, Reinhard Radermacher, David Didion

6. PERFORMING ORGANIZATION (If joint or other than NBS, see instructions)

NATIONAL BUREAU OF STANDARDS

DEPARTMENT OF COMMERCE

WASHINGTON, D.C. 20234

7. Contract/Grant No.

9. SPONSORING ORGANIZATION NAME AND COMPLETE ADDRESS (Street, City, State, ZIP)

U.S. Department of Energy

Oak Ridge National Laboratory

Washington, D.C. 20585

10. SUPPLEMENTARY NOTES

[D Document describes a computer program; SF-185, FIPS Software Summary, is attached.

11. ABSTRACT (A 200-word or less factual summary of most significant information. If document includes a significant bibliography or literature survey. mention it here)

Test and rating procedures are presented for gas-fired absorption devices operating in either the heating or cooling modes. These procedures are designed to include the effects of part-load and cyclic operation, variations in outdoor temperature, and frost formation during the heating mode. Both air-source and ground water source absorption heat pumps are considered, as well as air cooled and ground water cooled air-conditioners and water chillers. A calculation procedure is presented for estimating the heating and cooling seasonal performance and cost of operation of residential water chillers, air-conditioners, and heat pump units.

12. KEY WORDS (Six to tweive entries; alphabetical order: capitalize only proper names; and separate key words by semicolons) central air-conditioners; central heating equipment; cooling seasonal performance: heat pumps; heating seasonal performance; rating procedure; seasonal cost of operation; test method

13. AVAILABILITY

[X] Unlimited

$\square$ For Official Distribution. Do Not Release to NTIS

Order From Superintendent of Documents, U.S. Government Printing Office, Washington, D.C. 20402.

14. NO. OF PRINTED PAGES

78

15. Price

[X Order From National Technical Information Service (NTIS), Springfield, VA. 22I6! 


